\title{
Polyketide Ring Expansion Mediated by a Thioesterase, CEC Domain, in Azinomycin Biosynthesis: Characterization of AziB and AziG
}

\author{
Shogo Mori ${ }^{\dagger} \S$, Dinesh Simkhada ${ }^{\dagger} \S$, Huitu Zhang ${ }^{\dagger, \S}$, Megan S. Erb ${ }^{\ddagger}$, Yang Zhang ${ }^{\ddagger}$, Howard \\ Williams $^{\dagger}$, Dmytro Fedoseyenko ${ }^{\dagger}$, William K. Russell ${ }^{\dagger}$, Doyong Kim ${ }^{\dagger}$, Nathan Fleer ${ }^{\dagger}$, Steve \\ E. Ealick ${ }^{\ddagger}$, and Coran M. H. Watanabe ${ }^{\star}, \dagger$ \\ tDepartment of Chemistry, Texas A\&M University, College Station, Texas 77843, United States \\ ‡Department of Chemistry and Chemical Biology, Cornell University, Ithaca, New York, 14853, \\ United States
}

\begin{abstract}
The azinomycins are a family of potent anti-tumor agents with the ability to form interstrand crosslinks with DNA. This study reports on the unusual biosynthetic formation of the 5-methyl naphthoate moiety, which is essential for effective DNA association. While sequence analysis predicts that the polyketide synthase (AziB) catalyzes the formation of this naphthoate, 2methylbenzoic acid, a truncated single-ring product, is formed instead. We demonstrate that the thioesterase (AziG) acts as a chain elongation and cyclization (CEC) domain and is required for the additional two rounds of chain extension to form the expected product.
\end{abstract}

Polyketide synthases (PKSs) are megaenzymes, involving multiple catalytic domains, whose complex chemistry involves such processes as decarboxylative condensation, reduction, and dehydration and parallel that observed in fatty acid biosynthesis. ${ }^{1,2}$ Starter units (e.g. acetyl$\mathrm{CoA}$ ) and extender units (e.g. malonyl-CoA) are homologated to form ketide chains through Claisen-like condensations. In both fatty acid and polyketide biosynthesis, an acyl transferase (AT) domain transfers the starter and extender units onto an acyl carrier protein (ACP), which contains a phosphopantetheine arm enabling this domain to shuttle intermediates through the catalytic cycle. The ketosynthase (KS) domain accepts the starter unit from the ACP and subsequently catalyzes the condensation reaction with malonyl-CoA.

\footnotetext{
*Corresponding Author: watanabe@chem.tamu.edu.

$\S$ These authors contributed equally.

Primer sequences, strains and plasmids, SDS-PAGE of AziB, phosphopatetheinylation of AziB, reconstitution of PKS activity with S. sahachiroi cell free extract, confirmation of PKS by MALDI-MS, NMR of 2-methylbenzoic acid as formed by AziB, SDS-PAGE of AziG, demonstration of 2-methylbenzoic acid and 5-methylnaphthoic acid as formed by AziB by LC/MS, LC/MS traces of AziB + AziA6, AziA7, AziA8 product mixtures, gel filtration studies of AziB and AziB/AziG, Kinetic studies of AziG and its mutants, AziG data collection and refinement statistics. The atomic coordinates for AziG structures have been deposited in the Protein Data Bank as entries 5HMB (apo) and 5HMC (5-methyl naphthoic acid complex).
}

Author Contributions

The manuscript was written through contributions of all authors. All authors have given approval to the final version of the manuscript.

Supporting Information. Additional supplemental material. The Supporting Information is available free of charge on the ACS Publications website at: http://pubs.acs.org. 
In fatty acid biosynthesis, the process is completed by full reduction of the $\beta$-ketone in stepwise reactions involving ketoreductase (KR), dehydratase (DH), and enoyl reductase (ER) domains resulting in an inert hydrocarbon chain. The thioesterase (TE) domain promotes hydrolysis, releasing the fatty acid from the protein. In contrast, PKSs are selective and may or may not utilize reductive and/or dehydrative processing steps giving four possible functional states at the $\beta$-carbon during polyketide assembly. This enables the formation of different scaffolds and cyclization patterns.

It has long been held that aromatic polyketides are generated by Type I iterative PKSs in higher organisms where catalytic activities are housed in a single, multidomainal polypeptide chain. In contrast, in bacterial systems, aromatic polyketides have been thought to be biosynthesized by Type II PKSs, where each catalytic unit is discretely expressed and represents free-standing proteins that physically associate to perform the chemistry. In this report, we describe unforeseen chemistry exhibited by the azinomycin PKS.

The azinomycins (A and B, Figure 1) are anti-tumor agents produced by the terrestrial microorganism Streptomyces sahachiroi. ${ }^{3}$ In an early phase clinical investigation, azinomycin $\mathrm{B}$ has shown favorable results against 36 cases of malignant neoplasms, with the most promising effects observed against squamous cell carcinoma. ${ }^{4}$ In vitro studies suggest their biological activity resides in their ability to cross-link double stranded DNA through the actions of the electrophilic aziridine and epoxide moieties of the molecule. ${ }^{3,5,6}$ Noncovalent interactions made by the 5-methylnaphthoate and DNA are also essential for effective association and subsequent crosslinking of DNA. ${ }^{7,8}$ The formation of the 5methylnaphthoate moiety (Figure 1), would be expected to form by homologation of 1 acetyl CoA unit with 5 malonyl CoA units, as mediated by a polyketide synthase. The 3'methoxy group of the naphthoate is generated by oxidation and methylation as mediated by tailoring enzymes. ${ }^{3}$

\section{MATERIALS AND METHODS}

\section{Materials}

Streptomyces sahachiroi (NRRL 2485) was obtained from the American Type Culture Collection (ATCC). Cloning steps were performed in E. coli DH5a or E. coli TOP10. E. coli Rosetta (DE3) was used for protein expression. PCR was performed using Phusion High-Fidelity DNA Polymerase ${ }^{\circledR}$ (New England BioLabs). TOPO® XL PCR Cloning Kit (Invitrogen) was used for the cloning of genes. Plasmids used for gene expression were pET-24a $(+)$ and pET-21a(+) purchased from Novagen. Plasmid preparation and DNA purification were carried out using commercial kits (Qiagen). Restriction enzymes and other molecular biology reagents were from commercial sources (New England BioLabs). Radiolabeled coenzyme A (CoA), acetyl coenzyme A and malonyl coenzyme A substrates were purchased from PerkinElmer. Unlabeled coenzyme A (CoA), acetyl coenzyme A, malonyl coenzyme A substrates, $\beta$-nicotinamide adenine dinucleotide phosphate reduced form (NADPH) and S-(5'-adenosyl)-L-methionine chloride (SAM) were from Sigma Aldrich. 5-Bromo-1-naphthoic acid was purchased from Ark Pharm, Inc. The deuterated solvents for NMR experiments were purchased from Cambridge Isotope Laboratories and all other solvents were purchased from Fisher Scientific at the highest available grade. The 
liquid scintillation cocktails, Opti-Fluor and Opti-Fluor O, were purchased from PerkinElmer.

\section{Instrumentation}

Autoradiographic analyses were obtained on a BASReader, BAS-5000 phosphorimager (Fujifilm, Tokyo, Japan). Fermentations were carried out with a Fermentation Design Inc. Model \# MS21 (Allentown, PA, USA), $15 \mathrm{~L}$ total capacity. Sample collection by normal phase HPLC was carried out with a Varian Prostar HPLC System with 230 Pump and 330 UV/Vis Detector (Palo Alto, CA, USA) equipped with a Luna $5 \mu \mathrm{m}$ Silica $100 \AA$ A, LC Column $250 \times 10 \mathrm{~mm}$ (Phenomenex, Torrance, CA, USA). Reversed Phase HPLC experiments were performed with a Waters 600 Controller (Milford, MA, USA) equipped with a Prodigy $5 \mu \mathrm{m}$ ODS-2 $150 \AA$ A, LC Column $250 \times 4.6 \mathrm{~mm}$ (Phenomenex) and a Waters 2487 dual $\lambda$ absorbance detector. LC-MS was carried out on a Bruker MicroTOF-QII mass spectrometer coupled to an Agilent 1200 Infiniti series liquid chromatography system (Agilent Technologies) with a Prodigy $5 \mu \mathrm{m}$ ODS-2 $150 \AA$ A, LC Column $250 \times 4.6 \mathrm{~mm}$ (Phenomenex). NMR spectra were acquired in $\mathrm{CDCl}_{3}$ with a Varian Mercury 300 spectrometer or Bruker Advance III $500 \mathrm{MHz}$ spectrometer equipped with a $5 \mathrm{~mm} \mathrm{H}-\mathrm{C}-\mathrm{N}$ cryoprobe.

\section{Cloning of aziRB into Expression Vector pET-24a}

The PKS gene (aziB) was amplified by PCR using Streptomyces sahachiroi genomic DNA as a template. The PCR reaction was performed in a $50 \mu \mathrm{L}$ reaction mixture consisting of 2.5 U Phusion DNA Polymerase, $10 \mu \mathrm{L}$ 5X Phusion GC Reaction Buffer, $0.25 \mathrm{mM}$ each of the four dNTPs, 100 pmol of each primer (PKS-FP and PKS-RP, Table S1), and 50-100 ng of Streptomyces genomic DNA. The PCR program consisted of denaturation $\left(95^{\circ} \mathrm{C}\right.$ for $5 \mathrm{~min}$ ), followed by 30 cycles of denaturation $\left(95^{\circ} \mathrm{C}\right.$ for $\left.0.5 \mathrm{~min}\right)$, annealing $\left(55^{\circ} \mathrm{C}\right.$ for $0.5 \mathrm{~min}$ ), and extension $\left(72{ }^{\circ} \mathrm{C}\right.$ for $\left.5 \mathrm{~min}\right)$, and amplification was ended after a final extension. The resulting PCR product $(5.5 \mathrm{~kb})$ was cloned into the PCR® XL-TOPO Vector using the TOPO® XL PCR Cloning Kit (Invitrogen). Taking advantage of the naturally occurring NotI site at the end of the PKS open reading frame (ORF), the complete PKS ORF was isolated by EcoRI/NotI digestion, and inserted between the EcoRI/NotI sites of the E. coli expression vector pET-24a (EMD Millipore) to obtain pET-24a-aziB. Cloning of the gene was confirmed by DNA sequencing using BigDye ${ }^{\circledR}$ Terminator v3.1 Cycle Sequencing Kit (Applied Biosystems). The cloned plasmid was transformed into E. coli expression strain BL21(DE3) for overexpression. The resulting plasmid pET24a-aziB carries the kanamycin resistant gene, T7 promoter, lac operator, RBS site for the expression of the PKS and a 6xHis-tag at the $3^{\prime}$-end.

\section{Cloning of aziA6 into Expression Vector pET-24b}

Thioesterase gene, aziA6, was amplified from $S$. sahachiroi genomic DNA by PCR with primers AziA6-F and AziA6-R (Table S1). The PCR reaction was performed in a $25 \mu \mathrm{L}$ reaction mixture consisting of: $0.5 \mu \mathrm{L}$ Phusion High-Fidelity DNA Polymerase, $4 \mu \mathrm{L}$ Phusion GC Buffer, $15 \mathrm{ng}$ of $S$. sahachiroi genomic DNA, $0.5 \mu \mathrm{L}$ of each $20 \mathrm{mM}$ forward and reverse primer, $0.5 \mu \mathrm{L}$ of $20 \mathrm{mM}$ dNTP, $1.25 \mu \mathrm{L}$ of DMSO, and water to a total volume 
of $25 \mu \mathrm{L}$. The PCR program utilized an initial denaturation at $98{ }^{\circ} \mathrm{C}(30 \mathrm{~s}), 25$ cycles of 98 ${ }^{\circ} \mathrm{C}(10 \mathrm{~s}), 75^{\circ} \mathrm{C}$ for $20 \mathrm{~s}$, and $1 \mathrm{~min}$ at $72{ }^{\circ} \mathrm{C}$, and a final extension for $10 \mathrm{~min}$ at $72{ }^{\circ} \mathrm{C}$. The DNA fragment of aziA6 was purified by agarose gel extraction using the QIAquick Gel Extraction Kit (Qiagen, Venlo, Netherlands), and subsequently digested with restriction enzymes HindIII and XhoI. Following purification by agarose gel extraction, the DNA fragment was ligated into the HindIII/XhoI multiple cloning site of expression plasmid vector pET-24b, which contains a $6 x$ His-tag at the $3^{\prime}$-end. Cloning of the gene was confirmed by DNA sequencing using BigDye ${ }^{\circledR}$ Terminator v3.1 Cycle Sequencing Kit and the cloned plasmid transformed into E. coli expression strain BL21(DE3) for overexpression.

\section{Overexpression of Apo-AziB}

The $E$. coli strain harboring expression vector pET-24a-aziB was cultivated in $5 \mathrm{~mL}$ LB medium with $50 \mu \mathrm{g} / \mathrm{mL}$ kanamycin overnight. The bacterial cultures were inoculated into 1 $\mathrm{L} \mathrm{LB}$ medium and cultured at $37^{\circ} \mathrm{C}$ with shaking at $250 \mathrm{rpm}$ until $\mathrm{OD}_{600} 0.6-0.8$. After induction with the addition of $1 \mathrm{mM} \beta$-D-1-thiogalactopyranoside (IPTG), the cultures were incubated at $16{ }^{\circ} \mathrm{C}$ at $250 \mathrm{rpm}$ for $24 \mathrm{~h}$. The resulting cells were harvested by centrifugation at $7000 \mathrm{rpm}$ for $15 \mathrm{~min}$ and washed with deionized distilled water and buffer. AziB buffer included: $20 \mathrm{mM}$ potassium phosphate, $500 \mathrm{mM} \mathrm{NaCl}, 1 \mathrm{mM}$ dithiothreitol (DTT), $5 \mathrm{mM}$ imidazole, $20 \%$ glycerol, $\mathrm{pH}$ 7.4. The cell pellet was resuspended in $30 \mathrm{~mL}$ of buffer. After the addition of $1 \mathrm{mM}$ phenylmethylsulfonyl fluoride (PMSF), the cells were disrupted by sonication utilizing the following program: Branson Sonifier 450 (Branson Ultrasonics) fitted with a $5 \mathrm{~mm}$ micro-tip, output setting 6 , duty cycle $60 \%$, and 5 cycles of $30 \mathrm{~s}$ each. The cell debris was removed by centrifugation at $9,500 \mathrm{rpm}$ for $30 \mathrm{~min}$ and filtered with a $0.4 \mu \mathrm{m}$ syringe filter. The AziB cell extract was applied to pre-equilibrated HisTrap FF $5 \mathrm{~mL}$ columns (GE Healthcare Life Sciences) at $0.25 \mathrm{~mL} / \mathrm{min}$. The loaded column was washed with $150 \mathrm{~mL}$ of the column buffer with $40 \mathrm{mM}$ imidazole. The protein was eluted by the column buffer with $250 \mathrm{mM}$ imidazole. The buffer was exchanged into PPT buffer and concentrated to $10 \mathrm{mg} / \mathrm{mL}$ using a $10 \mathrm{kDa}$ centrifugal ultrafiltration unit (Amicon Ultra - 15 Centrifugal Filter Unit, Millipore).

\section{Streptomyces sahachiroi Cell-Free Extract Preparation}

Streptomyces sahachiroi (inoculated from spore stock derived from dehydrated plates) was grown on GYM plates for $5-7$ days at $28^{\circ} \mathrm{C}$ until sporulation. A $1 \mathrm{~cm}^{2}$ piece of the GYM plate was used to inoculate $100 \mathrm{~mL}$ of PS5 media in a $250 \mathrm{~mL}$ Erlenmeyer flask. The culture was incubated at $28{ }^{\circ} \mathrm{C}$ for $24 \mathrm{~h}$ at $250 \mathrm{rpm}$ (first stage culture). The first stage culture (50 $\mathrm{mL}$ ) was utilized to inoculate $600 \mathrm{~mL}$ of PS5 in $2 \mathrm{~L}$ baffled Erlenmeyer flasks. The cultures were grown for about $24 \mathrm{~h}$ at $28{ }^{\circ} \mathrm{C}, 250 \mathrm{rpm}$ (second stage culture). Two $600 \mathrm{~mL}$ second stage cultures were used to inoculate the $15 \mathrm{~L}$ fermenter containing $10 \mathrm{~L}$ of the reduced PS5 medium. Following inoculation, the fermenter was agitated at $300 \mathrm{rpm}$ and aerated with sterile filtered air $(8 \mathrm{~L} / \mathrm{min})$ for $48 \mathrm{~h}$. The mycelium was harvested by centrifugation and frozen in liquid nitrogen. The cell-free extract was prepared by combining frozen mycelium $(20 \mathrm{~g})$, glass beads $(28 \mathrm{~g}, 0.1 \mathrm{~mm})$, and cell-free extract buffer $(100 \mathrm{mM}$ potassium phosphate $\mathrm{pH} 7.5,50 \%$ glycerol, $2 \mathrm{mM}$ dDTT, and $1 \mathrm{mM}$ EDTA, $80 \mathrm{~mL}, 4{ }^{\circ} \mathrm{C}$ ) in a bead beater equipped with an ice water jacket. The cells were pulverized employing ten $1 \mathrm{~min}$ 
cycles separated by 1 min intervals to prevent warming of the protein extracts and subsequently centrifuged $(7,660 \mathrm{~g}, 15 \mathrm{~min})$ to give the crude cell-free extract. GYM plates contained per liter: 4 g glucose monohydrate, 4 g yeast extract (Difco), 10 gmalt extract (Difco), $2 \mathrm{~g} \mathrm{CaCO}_{3} \mathrm{~g}, 15 \mathrm{~g}$ Bacto-agar (Difco), and tap water; adjusted to $\mathrm{pH} 6.8$ prior to sterilization. PS5 medium contained per liter $5 \mathrm{~g}$ Pharmamedia (yellow cotton seed flour), 5 g soluble starch, $\mathrm{pH} 7.0$ prior to sterilization. Reduced PS5 medium contained per liter 1.25 g Pharmamedia, $1.25 \mathrm{~g}$ soluble starch, $\mathrm{pH} 7.0$ before sterilization.

\section{Reconstitution of the PKS, AziG with S. sahachiroi Cell Free Extract}

The conversion of the heterologously expressed apo-PKS to the holo-PKS was initially carried out with $S$. sahachiroi cell free extract (CFE), which contained all enzymes involved in azinomycin biosynthesis, including the PKS specific phosphopantetheinyl transferase(s). The expressed and purified apo-PKS $(25 \mathrm{mg}$ ) and $0.5 \mathrm{mg}$ coenzyme A were added to $15 \mathrm{~mL}$ of cell free extract and incubated at $28{ }^{\circ} \mathrm{C}$ for $60 \mathrm{~min}$. To detect the activity of the expressed "activated" PKS within the CFE, four reaction systems were set up as follows and each of them carried out in triplicate:

1. Boiled CFE $(5.0 \mathrm{~mL})+$ Co-factor solution $80 \mu \mathrm{L}$, acetyl-CoA $(1 \mathrm{mg} / \mathrm{mL}) 5$ $\mu \mathrm{L},{ }^{14} \mathrm{C}$-malonyl CoA $0.25 \mu \mathrm{Ci}$, CFE Buffer $1.0 \mathrm{~mL}$; negative control

2. Boiled CFE $(5.0 \mathrm{~mL})+$ Co-factor solution $80 \mu \mathrm{L}$, acetyl-CoA $(1 \mathrm{mg} / \mathrm{mL}) 5$ $\mu \mathrm{L},{ }^{14} \mathrm{C}$-malonyl CoA $0.25 \mu \mathrm{Ci}+$ Purified PKS $0.2 \mathrm{mg}$ (in $1 \mathrm{~mL}$ CFE buffer)

3. CFE $(5.0 \mathrm{~mL})+$ Co-factor solution $80 \mu \mathrm{L}$, acetyl-CoA $(1 \mathrm{mg} / \mathrm{mL}) 5 \mu \mathrm{L},{ }^{14} \mathrm{C}$ malonyl CoA $0.25 \mu \mathrm{Ci}$

4. CFE $(5.0 \mathrm{~mL})+$ Co-factor solution $80 \mu \mathrm{L}$, acetyl-CoA $(1 \mathrm{mg} / \mathrm{mL}) 5 \mu \mathrm{L},{ }^{14} \mathrm{C}$ malonyl CoA $0.25 \mu \mathrm{Ci}+$ Purified PKS $0.2 \mathrm{mg}$ (in $1 \mathrm{~mL}$ CFE buffer)

Following incubation at $28{ }^{\circ} \mathrm{C}$ for $24 \mathrm{~h}$, the samples were vortexed with dichloromethane (DCM; $5 \mathrm{~mL}$ ) and microcentrifuged for $5 \mathrm{~min}$ at 14,000 rpm. Organics were transferred to fresh tubes and evaporated to dryness. The organic residues were resolubilized in a minimal volume of dichloromethane $(60 \mu \mathrm{L})$ and applied to TLC (dichloromethane : methanol $=95$ : $5)$. The naphthoate spots $\left(\mathrm{R}_{\mathrm{f}}=0.3\right)$ were scraped from the TLC plates and transferred to vials containing OPTI-Fluor $O$ for scintillation counting analysis. To confirm the results the organic residues from the reaction systems were also analyzed by normal phase HPLC (Phenomenex silica column, $250 \times 10 \mathrm{~mm}$ ) and reverse phase HPLC (Phenomenex C8 column, $250 \times 4.6 \mathrm{~mm}$ ). The normal phase HPLC analysis conditions were 0-6.0\% $\mathrm{MeOH} / \mathrm{DCM}$ in $60 \mathrm{~min}, 3 \mathrm{~mL} / \mathrm{min}$. The reverse phase HPLC conditions were 20-100\% acetonitrile in $15 \mathrm{~min}$, followed by $100 \%$ acetonitrile for $5 \mathrm{~min}$, and $100-20 \%$ acetonitrile in $15 \mathrm{~min} ; 1.0 \mathrm{~mL} / \mathrm{min}$. The corresponding peaks were respectively collected, evaporated, and transferred to vials containing OPTI-Fluor $O$ for scintillation counting analysis.

\section{Cloning of svp into Expression Vector pET-21a}

The PPTase gene $s v p$ was amplified by PCR from pBS18 (provided by Prof. Ben Shen, Scripps Florida). The PCR reaction mixture contained 2.5 U Phusion DNA polymerase, 10 $\mu \mathrm{L} 5 \mathrm{X}$ Phusion GC Reaction Buffer, $0.25 \mathrm{mM}$ each of the four dNTPs, 100 pmol of each 
primer (SVP-F and SVP-R, Table S1), and 50-100 ng of pBS18 DNA in a final volume of $50 \mu \mathrm{L}$. The PCR program consisted of denaturation at $95^{\circ} \mathrm{C}$ for $5 \mathrm{~min}, 29$ cycles of $30 \mathrm{~s}$ at $95{ }^{\circ} \mathrm{C}, 30 \mathrm{~s}$ at $60^{\circ} \mathrm{C}$ and $1 \mathrm{~min}$ at $72{ }^{\circ} \mathrm{C}$, and $10 \mathrm{~min}$ at $72{ }^{\circ} \mathrm{C}$. The resultant PCR product was digested and cloned into the EcoRI/XhoI sites of the expression vector pET-21a to yield pET-21a-SVP in which Svp will be produced with a 6xHis tag at the C-terminus. Cloning of the gene was confirmed by DNA sequencing using the BigDye ${ }^{\circledR}$ Terminator v3.1 Cycle Sequencing Kit.

\section{Overexpression of Svp}

The constructed vector pET-21a-SVP was introduced into the host strain E. coli Rosetta DE3 giving a lawn of cells. LB broth $(5 \mathrm{~mL})$ containing $100 \mu \mathrm{g} / \mathrm{mL}$ ampicillin was inoculated with a single colony and incubated overnight at $37^{\circ} \mathrm{C}, 250 \mathrm{rpm}$. The $5 \mathrm{~mL}$ overnight culture was used to inoculate $1 \mathrm{~L}$ of $\mathrm{LB}$ medium and the culture was grown utilizing the same conditions until $\mathrm{OD}_{600}=0.8$. The culture was induced with $1 \mathrm{mM} \mathrm{IPTG}$ and incubated at $16{ }^{\circ} \mathrm{C}, 250 \mathrm{rpm}$ for $24 \mathrm{~h}$. The cells were harvested by centrifugation at 7000 rpm for $15 \mathrm{~min}$ and washed with deionized distilled water and phosphopantetheinylation (PPT) buffer (5 mM DTT, $10 \mathrm{mM} \mathrm{MgCl} 2,75 \mathrm{mM}$ Tris-HCl, pH 8.0, and 20\% glycerol). After the addition of $1 \mathrm{mM}$ phenylmethylsulfonyl fluoride (PMSF), the cells were disrupted by sonication utilizing the following program: Branson Sonifier 450 (Branson Ultrasonics, Danbury, CT) fitted with a $5 \mathrm{~mm}$ micro-tip, output setting 6 , duty cycle $60 \%$, and 5 cycles of $30 \mathrm{~s}$ each. The cell debris was removed by centrifugation at $9,500 \mathrm{rpm}$ for $30 \mathrm{~min}$ and filtered with a $0.4 \mu \mathrm{m}$ syringe filter.

\section{Phosphopantetheinylation of AziB with ${ }^{3} \mathrm{H}$-pantetheine-CoA}

The $400 \mu \mathrm{L}$ crude solution of Svp was mixed with $100 \mu \mathrm{L}(1 \mathrm{mg})$ of purified apo-AziB solution. Phosphopantetheinylation was initiated by adding $0.8 \mu \mathrm{Ci}\left[{ }^{3} \mathrm{H}\right.$-pantetheinel]-CoA and carried out at $28{ }^{\circ} \mathrm{C}$ for $2 \mathrm{~h}$. The reaction mixture was concentrated to $100 \mu \mathrm{L}$ with a centrifugal ultrafiltration unit (Amicon Ultra $15 ; 0.5 \mathrm{~mL}$ ), and $12 \mu \mathrm{L}$ of each sample evaluated on a $12 \%$ SDS-PAGE gel. The resulting gel was washed with deionized distilled water, dried between two sheets of cellulose membrane, exposed to X-ray film for a week (Imaging Plate BAS-MS 2025, Fujifilm), and visualized with a phosphoimager.

\section{Reconstitution of holo-PKS AziB Activity and Analysis by Autoradiography}

Cells from 5 L PKS expression cultures and 3 L Svp expression cultures were collected by centrifugation. The cultures were mixed and resuspended in $100 \mathrm{~mL}$ of PPT buffer and subsequently lysed by sonication. The cellular debris was removed by centrifugation at $9,500 \mathrm{rpm}$ for $30 \mathrm{~min}$. The supernatant, which contained both the apo-PKS and Svp, was filtered with a $0.2 \mu \mathrm{m}$ syringe filter to give $\sim 90 \mathrm{~mL}$ of filtered protein extract. To posttranslationally modify the PKS and generate the holo-form, $4 \mathrm{mg}$ pantetheine-CoA was added to the supernatant and the mixture was incubated at $28{ }^{\circ} \mathrm{C}$ for $1 \mathrm{~h}$. After the reaction, the mixture was applied to a pre-equilibrated His-Trap FF $5 \mathrm{~mL}$ column (GE Healthcare Life Science), and using the same purification procedures for the apo-PKS, about $100 \mathrm{mg}$ of purified holo-PKS was obtained. The purified holo-PKS was buffer exchanged into PKS reaction buffer (75 mM Tris- $\mathrm{HCl} \mathrm{pH} 8.0,10 \mathrm{mM} \mathrm{MgCl} 2,5 \mathrm{mM}$ DTT, and $20 \%$ glycerol) by 
centrifugal ultrafiltration (Amicon Ultra-15 Centrifugal Filter Unit) to a final concentration of $1 \mathrm{mg} / \mathrm{mL}$.

To investigate the activity of the purified holo-PKS, $10 \mathrm{mg}$ of the purified holo-PKS (in 10 mL PKS reaction buffer) was incubated with $150 \mu \mathrm{L}$ of co-factor solution (FAD, $1 \mathrm{mg}$; SAM, $1 \mathrm{mg}$; NADPH, $1 \mathrm{mg}$ in $1 \mathrm{~mL}$ of deionized distilled water) and radiolabeled substrates $\left({ }^{14} \mathrm{C}\right.$-acetyl-CoA $0.1 \mu \mathrm{Ci}, 14 \mathrm{C}$-malonyl CoA $\left.0.5 \mu \mathrm{Ci}\right)$ at $28{ }^{\circ} \mathrm{C}$ for $2 \mathrm{~h}$. The reaction system was adjusted to $\mathrm{pH} 12$ by treating with $0.5 \mathrm{M} \mathrm{NaOH}$ and incubated at room temperature for about $10 \mathrm{~min}$ to hydrolyze the thioester. The $\mathrm{pH}$ of the mixture was adjusted to $\mathrm{pH} 5$ with 1 $\mathrm{M} \mathrm{HCl}$ and extracted with $5 \mathrm{~mL}$ of dichloromethane. Organics were transferred to fresh tubes and evaporated to dryness. The organic residues were resolubilized in a minimal volume of dichloromethane $(60 \mu \mathrm{L})$ and applied to TLC (DCM : MeOH $=95: 5)$. The PKS reaction products were visualized by autoradiography on X-ray film (Fuji Medical system).

\section{Reconstitution of 2-Methylbenzoic Acid Formation by Phosphopantetheinylated AziB}

To identify the major product produced by the holo-PKS, $80 \mathrm{mg}$ of the purified holo-PKS (in $80 \mathrm{~mL}$ PKS reaction buffer) was incubated with $3 \mathrm{mg}$ of unlabeled acetyl-CoA, $15 \mathrm{mg}$ of malonyl-CoA and $1.0 \mathrm{~mL}$ of co-factor solution. The resulting reaction mixture was incubated at $28{ }^{\circ} \mathrm{C}$ for $12 \mathrm{~h}$. The reaction system was adjusted to $\mathrm{pH} 12$ by treating with 0.5 $\mathrm{M} \mathrm{NaOH}$ and incubated at room temperature for about $10 \mathrm{~min}$ to hydrolyze the thioester. The $\mathrm{pH}$ of the mixture was adjusted to $\mathrm{pH} 5$ with $1 \mathrm{M} \mathrm{HCl}$ and extracted with dichloromethane $(100 \mathrm{~mL})$. Organics were transferred to fresh tubes and evaporated to dryness for NMR analysis. The product was visualized by TLC by resolubilizing the compound in a minimal volume of dichloromethane and applying it to TLC (dichloromethane : methanol $=95: 5$ ).

\section{Confirmation of the PKS, AziB by MALDI-MS}

To confirm the identity of the PKS by MS, approximately $2 \mathrm{~mm}$ protein bands were excised from a polyacrylamide gel stained with Coomassie Blue. The excised gel bands were digested following standard protocols. Briefly, the method involved a series of washing and dehydration steps with $25 \mathrm{mM} \mathrm{ABC}$ and $\mathrm{ACN}$, prior to digestion with trypsin at $37{ }^{\circ} \mathrm{C}$ for 4-12 h. The resulting tryptic peptides were combined with matrix (a-cyano-4hydroxycinnamic acid), mixed thoroughly and spotted onto a MALDI plate for analysis. MS data were acquired using the reflection detector in positive mode using 25 laser shots ( 25 shots per sub-spectrum). Tandem mass spectra were acquired in positive ion mode using a Model 4800 Proteomics Analyzer (Applied Biosystems, Framingham, Massachusetts, USA). $\mathrm{CID}$ acceleration of $2 \mathrm{kV}$ was used and the collision gas was atmospheric. The mass spectra obtained in these experiments were analyzed using Data Explorer ${ }^{\mathrm{TM}}$. Fragment ions are labeled using the nomenclature suggested by Roepstorff and Fohlman as modified by Biemann. All MS and MS/MS data were searched against the Swiss-Prot protein sequence database using the GPS Explorer (Applied Biosystems) software

\section{Cloning of aziA7}

Two oligonucleotides, AziA7-F and AziA7-R (Table S1), containing EcoRI and HindIII sites, respectively, were used to amplify the aziA7 gene from the genomic DNA of $S$. 
sahachiroi. The PCR conditions were as follows: $4 \mu \mathrm{L}$ of $5 \mathrm{X}$ Phusion buffer, $0.4 \mu \mathrm{L}$ of 10 $\mathrm{mM}$ of dNTPs, $1 \mu \mathrm{L}$ of each primer $(10 \mu \mathrm{M}), 0.2 \mu \mathrm{L}$ Phusion High Fidelity DNA

Polymerase, $1 \mu \mathrm{l}$ of $S$. sahachiroi genomic DNA (15 ng) and nuclease free water to $20 \mu \mathrm{L}$. The PCR thermocycler conditions were as follows: initial denaturation at $98^{\circ} \mathrm{C}$ for $30 \mathrm{sec}$, 30 cycles of denaturation at $98^{\circ} \mathrm{C}$ for $10 \mathrm{sec}$, annealing at $62^{\circ} \mathrm{C}$ for $1 \mathrm{~min}$, and polymerization at $72^{\circ} \mathrm{C}$ for $1 \mathrm{~min}$. The DNA fragment of $a z i A 7$ was purified by agarose gel extraction using the QIAquick Gel Extraction Kit (Qiagen), and subsequently digested with restriction enzymes EcoRI and HindIII. Following purification by agarose gel extraction, the DNA fragment was ligated into the EcoRI/HindIII multiple cloning site of expression plasmid vector pET-24a, which contains a 6xHis-tag at the 3 -end. Cloning of the gene was confirmed by DNA sequencing using BigDye ${ }^{\circledR}$ Terminator v3.1 Cycle Sequencing Kit and the cloned plasmid transformed into E. coli expression strain BL21(DE3) for overexpression.

\section{Cloning of aziA8}

Oligonucleotide primers, AziA8F and AziA8R (Table S1), containing EcoRI and HindIII sites, respectively, were used to amplify the aziA8 gene from the genomic DNA of $S$. sahachiroi. The PCR conditions were as follows: $4 \mu \mathrm{L}$ of $5 \mathrm{X}$ Phusion buffer, $0.4 \mu \mathrm{L}$ of 10 $\mathrm{mM}$ of dNTPs, $1 \mu \mathrm{L}$ of each primer $(10 \mu \mathrm{M}), 0.2 \mu \mathrm{L}$ Phusion High Fidelity DNA Polymerase, $1 \mu \mathrm{l}$ of $S$. sahachiroi genomic DNA (15 ng) and nuclease free water to $20 \mu \mathrm{L}$. The PCR thermocycler conditions were as follows: initial denaturation at $98{ }^{\circ} \mathrm{C}$ for $30 \mathrm{sec}$, 30 cycles of denaturation at $98{ }^{\circ} \mathrm{C}$ for $10 \mathrm{sec}$, annealing at $62{ }^{\circ} \mathrm{C}$ for $1 \mathrm{~min}$, and polymerization at $72{ }^{\circ} \mathrm{C}$ for $1 \mathrm{~min}$. The DNA fragment of $a z i A 8$ was purified by agarose gel extraction using the QIAquick Gel Extraction Kit (Qiagen), and subsequently digested with restriction enzymes EcoRI and $\underline{H i n d I I I}$. Following purification by agarose gel extraction, the DNA fragment was ligated into the EcoRI/HindIII multiple cloning site of expression plasmid vector pET-24a, which contains a 6xHis-tag at the 3 -end. Cloning of the gene was confirmed by DNA sequencing using BigDye ${ }^{\circledR}$ Terminator v3.1 Cycle Sequencing Kit and the cloned plasmid transformed into E. coli expression strain BL21(DE3) for overexpression.

\section{Cloning of aziG}

Two oligonucleotides, AziG-F and AziG-R (Table S1), containing EcoRI and HindIII sites, respectively, were used to amplify the aziG gene from the genomic DNA of S. sahachiroi. The PCR conditions were as follows: $4 \mu \mathrm{L}$ of $5 \mathrm{X}$ Phusion buffer, $0.4 \mu \mathrm{L}$ of $10 \mathrm{mM}$ of dNTPs, $1 \mu \mathrm{L}$ of each primer $(10 \mu \mathrm{M}), 0.2 \mu \mathrm{L}$ Phusion High Fidelity DNA Polymerase, $1 \mu \mathrm{l}$ of of $S$. sahachiroi genomic DNA (15 ng) and nuclease free water to $20 \mu \mathrm{L}$. The PCR thermocycler conditions were as follows: initial denaturation at $98{ }^{\circ} \mathrm{C}$ for $30 \mathrm{sec}, 30$ cycles of denaturation at $98{ }^{\circ} \mathrm{C}$ for $10 \mathrm{sec}$, annealing at $62{ }^{\circ} \mathrm{C}$ for $1 \mathrm{~min}$, and polymerization at 72 ${ }^{\circ} \mathrm{C}$ for $1 \mathrm{~min}$. The DNA fragment of $a z i G$ was purified by agarose gel extraction using the QIAquick Gel Extraction Kit (Qiagen), and subsequently digested with restriction enzymes EcoRI and HindIII. Following purification by agarose gel extraction, the DNA fragment was ligated into the EcoRI/HindIII multiple cloning site of expression plasmid vector pET-24a, which contains a 6xHis-tag at the $3^{\prime}$-end. Cloning of the gene was confirmed by DNA 
sequencing using BigDye ${ }^{\circledR}$ Terminator v3.1 Cycle Sequencing Kit and the cloned plasmid transformed into E. coli expression strain BL21(DE3) for overexpression.

\section{X-ray Crystallographic Analysis of AziG}

A. AziG Overexpression, and Purification-The pET-24a-aziG vector was transformed into BL21(DE3) and plated on selective kanamycin $(30 \mu \mathrm{g} / \mathrm{mL})$ containing LB agar and incubated at $37^{\circ} \mathrm{C}$ overnight. For each $1.5 \mathrm{~L}$ volume to be grown, a single colony was selected and transferred to $10 \mathrm{~mL}$ sterile $\mathrm{LB}$ medium supplemented with $30 \mu \mathrm{g} / \mathrm{mL}$ of kanamycin and shaken overnight at $37^{\circ} \mathrm{C}$. After approximately $18 \mathrm{~h}, 10 \mathrm{~mL}$ of overnight starter culture was added directly to $1.5 \mathrm{~L}$ volumes of sterile $\mathrm{LB}$. The flasks were shaken at $200 \mathrm{rpm}$ at $37^{\circ} \mathrm{C}$ until the media reached an $\mathrm{OD}_{600}$ of $\sim 0.6$, at which point the incubator temperature was turned down to $15{ }^{\circ} \mathrm{C}$. After the incubator reached the induction temperature of $15{ }^{\circ} \mathrm{C}$ and the media $\mathrm{OD}_{600}$ was $\sim 0.8$, solid IPTG was added to give a final concentration of $0.5 \mathrm{mM}$. After induction of protein expression by addition of IPTG, the cells were incubated with shaking for approximately $18 \mathrm{~h}$ prior to harvesting. The cells were harvested by centrifugation at $2000 \mathrm{~g}$ for $15 \mathrm{~min}$ and subsequently stored in $3 \mathrm{~L}$ aliquots, frozen at $-20{ }^{\circ} \mathrm{C}$ until purification.

To purify the AziG protein, the $3 \mathrm{~L}$ cell pellet was thawed and resuspended in $45 \mathrm{~mL}$ of lysis buffer $(50 \mathrm{mM}$ Tris- $\mathrm{HCl}, 300 \mathrm{mM} \mathrm{NaCl}$, and $20 \mathrm{mM}$ imidazole at $\mathrm{pH}$ 7.5). The resuspended cells were lysed on ice with three rounds of sonication for $3 \mathrm{~min}$, with $10 \mathrm{~min}$ off after each round. The lysed cell suspension was centrifuged at $40,000 \mathrm{~g}$ for $30 \mathrm{~min}$ at $4{ }^{\circ} \mathrm{C}$. The cleared lysate was decanted and loaded onto a $2 \mathrm{~mL} \mathrm{Ni-NTA}$ column (Qiagen) pre-equilibrated with lysis buffer. Following loading of the cleared lysate, the column was washed with $50 \mathrm{~mL}$ of lysis buffer at a flow rate of $1 \mathrm{~mL} / \mathrm{min}$ to remove non-specifically bound contaminants.

To elute AziG, $20 \mathrm{~mL}$ of elution buffer $(50 \mathrm{mM}$ Tris- $\mathrm{HCl}, 300 \mathrm{mM} \mathrm{NaCl}$, and $250 \mathrm{mM}$ imidazole at a final $\mathrm{pH}$ of 7.5) was loaded onto the column and the volume containing AziG was collected. AziG purity was assessed by SDS-PAGE gel electrophoresis. The sample was buffer exchanged into $10 \mathrm{mM}$ Tris- $\mathrm{HCl}, 50 \mathrm{mM} \mathrm{NaCl}$ at a $\mathrm{pH}$ of 7.5 by overnight dialysis and concentrated to $10 \mathrm{mg} / \mathrm{ml}$ using a centrifugal filter device with a molecular weight cut off of 3,000 Da. The purified protein was aliquoted and flash frozen into liquid nitrogen for storage at $-80{ }^{\circ} \mathrm{C}$. This purification process yielded approximately $25 \mathrm{mg} / \mathrm{L}$ of purified cell culture.

B. Crystallization of AziG-The hanging drop vapor diffusion method was used for crystallization. In this method, the frozen protein aliquots were thawed on ice and equal volumes of protein and reservoir solution were mixed and equilibrated at $22{ }^{\circ} \mathrm{C}$ against a total volume of $500 \mu \mathrm{L}$ well solution. Using the commercially available sparse matrix Wizard screens (Emerald Biosystems), three crystallization conditions were identified. Crystals were observed in Wizard I condition $13(1.32 \mathrm{M}$ ammonium sulfate and $0.1 \mathrm{M}$ cacodylate pH 6.5), Wizard II condition 39 (0.1 M CAPS pH 10.5, $0.2 \mathrm{M} \mathrm{NaCl}$, and $20 \%$ PEG 8,000), and Wizard III condition 33 (1.6 M magnesium sulfate and 0.1 M MES pH 6.5). Optimized conditions are: (1) $1.25 \mathrm{M}$ ammonium sulfate and $0.1 \mathrm{M}$ cacodylate $\mathrm{pH} 6.0$; (2) $1.6 \mathrm{M}$ magnesium sulfate and 0.1 M MES pH 5.5; and (2) 0.1 M CAPS pH 10.8, 0.2 M 
$\mathrm{NaCl}$, and 14\% PEG 8000. In all three conditions, crystals with similar morphologies appeared overnight. The crystals were square bipyramidal and grew to maximum dimensions of $60 \mu \mathrm{m} \times 40 \mu \mathrm{m} \times 40 \mu \mathrm{m}$ in two weeks. The crystals were cryoprotected for data collection in a solution composed of their mother liquor supplemented with $10 \%(\mathrm{v} / \mathrm{v})$ glycerol and $10 \%$ (v/v) ethylene glycol before flash freezing in liquid nitrogen. For the ligand complex, the crystals were soaked with $10 \mathrm{mM}$ 5-methylnaphthoic acid for $30 \mathrm{~min}$ before cryoprotection and flash freezing.

C. X-ray Data Collection and Processing-X-ray diffraction experiments for the unliganded structure were conducted at CHESS (Cornell High Energy Synchrotron Source) beamline F1 using a Q270 detector (Area Detector Systems Corporation) at a distance of $305 \mathrm{~mm}$ and wavelength of $0.91830 \AA$. The oscillation method was used with cryocooling with a $1^{\circ}$ rotation and $10 \mathrm{~s}$ exposures per frame for a total of $90^{\circ}$. Crystals grown in all three conditions were tested for diffraction quality. The data sets reported are for crystals grown in the ammonium sulfate containing condition. The diffraction data for the 5-methyl naphthoic acid complex were collected at APS beamline 24-ID-C with cryocooling using a PILATUS 6MF pixel array detector (Dectris) at a distance of $400 \mathrm{~mm}$ and wavelength of 0.97919 , with $0.2^{\circ}$ oscillation and $0.2 \mathrm{~s}$ exposure time per frame for a total of $90^{\circ}$. HKL2000 ${ }^{9}$ and NECAT-developed automatic data processing pipeline RAPD were used for indexing, integration, and data scaling. Complete data collection and refinement statistics are listed in Table S3.

\section{Structure Determination, Model Building, and Refinement-The SsAziG} crystal belongs to space group $I 4{ }_{1} 22$ and contains one promoter per asymmetric unit and a Matthew's coefficient ${ }^{10}$ of $2.73 \AA^{3} / \mathrm{Da}$, corresponding to a solvent content of $54.9 \%$. The structures of SsAziG were determined using the molecular replacement method, with Mycobacterium tuberculosis thioesterase (PDB ID: 3S4K) as the initial model. The program Chainsaw ${ }^{11}$ was used to create a search model from $3 \mathrm{~S} 4 \mathrm{~K}$. Molecular replacement using this search model was conducted with MolRep. ${ }^{12}$ Iterative rounds of model building were conducted using COOT, ${ }^{13}$ with refinement using RefMac $5^{14}$ in initial rounds, and PHENIX.refine ${ }^{15}$ in final rounds. The quality of the final structure was assessed using MolProbity. ${ }^{16}$ Structure refinement for AziG and AziG/5-methyl naphthoic acid complex converged with $R_{\text {work }} / R_{\text {free }}$ of $22.2 \% / 26.2 \%$ and $18.5 \% / 21.8 \%$, respectively. Complete refinement statistics for both structures are listed in Table S3.

\section{Gel Filtration Analysis of AziG: Evaluation of its Native State}

The native form of AziG in solution was assessed by gel filtration (size-exclusion) chromatography. Protein samples (standards and AziG, $1 \mathrm{mg}$ of each) were injected into a pre-equilibrated (10 $\mathrm{mM}$ phosphate and $150 \mathrm{mM} \mathrm{NaCl}$ at $\mathrm{pH}$ 7.2) gel filtration column (Superdex 75 PC HiLoad 16/60, GE Healthcare) at room temperature. The elution volume was measured by detecting the sample elution at a UV absorbance of $\lambda 280 \mathrm{~nm}$. The calibration curve was generated with protein standards: bovine serum albumin (molecular mass, $67 \mathrm{kDa}$; elution volume, $55.6 \mathrm{~mL})$, ovalbumin ( $45 \mathrm{kDa} ; 61.0 \mathrm{~mL})$, carbonic anhydrase $(29 \mathrm{kDa} ; 69.2 \mathrm{~mL})$, and cytochrome $\mathrm{C}(13 \mathrm{kDa} ; 81.6 \mathrm{~mL})$ and plotting elution volume $(\mathrm{mL})$ vs. molecular mass of standard $(\mathrm{kDa})$. 
The elution volume of native AziG was $55.6 \mathrm{~mL}$, thus the molecular mass was calculated as $62 \mathrm{kDa}$. Since the theoretical mass of expressed AziG (containing plasmid restriction site and $6 \times$ Histidine) is $15.8 \mathrm{kDa}$, it is predicted that the native state of AziG in solution is that of a tetramer ( $\pm 2 \%$ error).

\section{Gel Filtration Analysis of AziB-AziG Mixture: Evaluation of Stable Complex Formation}

It was assessed by gel filtration whether AziB and AziG stably interact with each other in solution. Protein samples (AziB and AziB+AziG, $0.5 \mathrm{mg}$ of each) were injected into a preequilibrated (10 mM phosphate, $150 \mathrm{mM} \mathrm{NaCl}$, and $20 \%$ glycerol at $\mathrm{pH} 7.4)$ gel filtration column (Superdex 200 PG HiLoad 16/60, GE Healthcare) at room temperature. The elution volume was measured by detecting the sample elution at a UV absorbance of $\lambda 280 \mathrm{~nm}$.

\section{Site-directed Mutagenesis of aziG}

H44, H48, E57, S58 and S61 of AziG were mutated to alanine using a QuikChange II SiteDirected Mutagenesis Kit (Agilent Technologies) on plasmid pET-24a-AziG. Primers containing point mutations were used to amplify mutated plasmids for each (Table S1). Primers for H44A, E57A, S58A, and S61A mutations were AziG-H44A-F and AziG-H44AR, AziG-H48A-F and AziG-H48A-R, AziG-E57A-F and AziG-E57A-R, AziG-S58A-F and AziG-S58A-R, and AziG-S61A-F and AziG-S61A-R, respectively. The PCR reaction was performed in a $50 \mu \mathrm{L}$ reaction mixture consisting of: $1 \mu \mathrm{L}$ of PfuUltra HF DNA polymerase (Agilent Technologies, Santa Clara, CA, USA), $5 \mu \mathrm{L}$ of $10 \mathrm{X}$ reaction buffer, $1 \mu \mathrm{L}$ of dNTP mix, $10 \mathrm{ng}$ of pET-AziG, $125 \mathrm{ng}$ of each forward and reverse primer, and water to $50 \mu \mathrm{L}$. PCR reactions utilized the following program: initial denaturation for $30 \mathrm{~s}$ at $95{ }^{\circ} \mathrm{C}$ and 12 cycles of $30 \mathrm{~s}$ at $95{ }^{\circ} \mathrm{C}, 1 \mathrm{~min}$ at $55^{\circ} \mathrm{C}$, and $6 \mathrm{~min}$ at $68{ }^{\circ} \mathrm{C}$. The amplified plasmids were treated with $D p n I$ restriction enzyme for $3 \mathrm{~h}$ to degrade the parent, wild-type methylated DNA. The mutated plasmids were transformed into $E$. coli DH10b by electroporation, and the mutations were confirmed by DNA sequencing. The plasmids were subsequently transformed into BL21(DE3) for overexpression.

\section{Sample Preparation for Analysis by LC/MS and Evaluation of Kinetics}

\section{A. Overexpression of AziB, Svp, AziA6, AziA7, AziA8, AziG, and AziG Mutants} -AziB, Svp, AziA6, AziA7, AziA8, AziG, and AziG mutants were each overexpressed in the same manner. $E$. coli strains that contained their respective expression plasmids were cultured in $5 \times 5 \mathrm{~mL}$ LB media for AziB, $3 \times 5 \mathrm{~mL}$ for Svp, $4 \times 5 \mathrm{~mL}$ for AziA6, and $5 \mathrm{~mL}$ for AziA7, AziA8, and AziGs overnight supplemented with the appropriate antibiotics (50 $\mu \mathrm{g} / \mathrm{mL}$ kanamycin for AziB, AziA6, AziA7, AziA8, and AziGs and $100 \mu \mathrm{g} / \mathrm{mL}$ ampicillin for Svp). Note: the differing amounts of each culture reflect optimization to account for differences in expression levels and loss of protein during purification. Each of the $5 \mathrm{~mL}$ overnight cultures was inoculated into $1 \mathrm{~L}$ LB medium and grown until $\mathrm{OD}_{600} 0.6-0.8$. Production of proteins was induced with $1 \mathrm{mM}$ IPTG and incubated at $16{ }^{\circ} \mathrm{C}, 250 \mathrm{rpm}$ for $22 \mathrm{~h}$. The resulting cells were harvested by centrifugation at $7000 \mathrm{rpm}$ for $15 \mathrm{~min}$. The cells were washed with deionized distilled water and the appropriate buffer: PPT buffer for AziB and Svp and column buffer ( $1 \mathrm{mM}$ DTT, $500 \mathrm{mM} \mathrm{NaCl}, 5 \mathrm{mM}$ imidazole, $50 \mathrm{mM}$ potassium phosphate, $\mathrm{pH} 7.5$, and $20 \%$ glycerol) for AziA6, AziA7, AziA8, and AziGs. The remaining 
steps were performed on ice. The cells were resuspended in their respective buffers: AziA6 $(30 \mathrm{~mL})$, AziA7 $(30 \mathrm{~mL})$, AziA8 $(30 \mathrm{~mL})$, each AziG $(30 \mathrm{~mL})$ and AziB + Svp (a total of $100 \mathrm{~mL}$ ), which was subsequently mixed together. PMSF was added to give a final concentration of $1 \mathrm{mM}$ shortly before the cells were lysed by sonication. Sonication was carried out with a Branson Sonifier 450 (Branson Ultrasonics) fitted with a $5 \mathrm{~mm}$ micro-tip, output setting 6 , duty cycle $60 \%$, and 5 cycles for 30 s each. The cell debris was removed by centrifugation at 9,900 rpm for $45 \mathrm{~min}$, twice and subsequently passed through a $0.4 \mu \mathrm{m}$ syringe filter. The protein solution was stored at $4{ }^{\circ} \mathrm{C}$.

\section{B. Posttranslational Modification of AziB with Svp and Coenzyme A-}

Approximately $90 \mathrm{~mL}$ of apo-AziB and Svp crude protein extract was obtained following cell lysis and centrifugation. Apo-AziB was converted to the holo-form by adding $5 \mu \mathrm{mol}$ of coenzyme A, giving a final concentration of $\sim 5.5 \mu \mathrm{M}$. The sample was incubated at $28^{\circ} \mathrm{C}$, $250 \mathrm{rpm}$ for $1 \mathrm{~h}$. Any resulting precipitation formed during incubation was removed by centrifugation, 9,900 rpm for $45 \mathrm{~min}$. Holo-AziB/Svp were purified by nickel affinity chromatography. A HisTrap FF $5 \mathrm{~mL}$ column was equilibrated with PPT buffer and subsequently loaded with the protein mixture at a rate of $0.25 \mathrm{~mL} / \mathrm{min}$. The column was washed with $200 \mathrm{~mL}$ of PPT column buffer (1 mM DTT, $500 \mathrm{mM} \mathrm{NaCl}, 40 \mathrm{mM}$ imidazole, $75 \mathrm{mM}$ Tris-HCl, $\mathrm{pH}$ 8.0, and 20\% glycerol) and eluted with $30 \mathrm{~mL}$ of PPT column buffer supplemented with $250 \mathrm{mM}$ imidazole. The buffer was exchanged to the AziB-AziG reaction buffer ( $50 \mathrm{mM}$ potassium phosphate, $\mathrm{pH} 7.5$, and $20 \%$ glycerol). The purity and quantity of holo-AziB and Svp were assessed by $8 \%$ (v/v) SDS-PAGE and Bradford assay utilizing the Bio-Rad Protein Assay kit (Bio-Rad Laboratories); bovine serum albumin (BSA) was used as a standard.

\section{Purification of AziA6, AziA7, AziA8, AziG, and AziG mutants-The crude} solutions, which contained AziA6, AziA7, AziA8 or AziGs were applied to pre-equilibrated HisTrap FF $5 \mathrm{~mL}$ columns at $0.25 \mathrm{~mL} / \mathrm{min}$. The loaded columns were treated as follows:

For AziA6, the column was washed with $200 \mathrm{~mL}$ of column buffer supplemented with $40 \mathrm{mM}$ imidazole, and eluted with $30 \mathrm{~mL}$ of column buffer supplemented with $250 \mathrm{mM}$ imidazole

For AziA7 and AziA8 the columns were washed with $240 \mathrm{~mL}$ of column buffer supplemented with $10 \mathrm{mM}$ and $20 \mathrm{mM}$ imidazole each and eluted with $50 \mathrm{~mL}$ of column buffer supplemented with $100 \mathrm{mM}$ imidazole

For AziG and its mutants the column was washed with $200 \mathrm{~mL}$ of column buffer supplemented with $60 \mathrm{mM}$ imidazole and eluted with $30 \mathrm{~mL}$ of column buffer supplemented with $250 \mathrm{mM}$ imidazole

The buffer was exchanged to AziB-AziG reaction buffer (potassium phosphate, $50 \mathrm{mM}$; glycerol, 20\%; $\mathrm{pH} 7.5$ ) by centrifugal ultrafiltration units for $10 \mathrm{kDa}$ (Amicon Ultra - 15) except for AziA6. An additional purification step was required for AziA6. The buffer was exchanged to sephadex column buffer ( $20 \mathrm{mM}$ sodium phosphate, $150 \mathrm{mM} \mathrm{NaCl}, \mathrm{pH} 7.5$ ). A Sephadex G-50 fine size exclusion column, $1 \mathrm{~m}$ height, with $\sim 200 \mathrm{~mL}$ bed volume was equilibrated with Sephadex column buffer. The AziA6 solution was concentrated to $1.5 \mathrm{~mL}$ 
and loaded onto the column. Fractions were collected every $3 \mathrm{~mL}$ and were later analyzed for quantity and purity by Bradford assay and 12\% (v/v) SDS-PAGE. The purified AziA6 fractions were combined together and the buffer was exchanged to AziB-AziG reaction buffer.

\section{Reconstitution of 5-Methylnaphthoic Acid Formation}

Acetyl CoA $(50 \mu \mathrm{M})$, malonyl CoA $(250 \mu \mathrm{M})$, NADPH $(10 \mu \mathrm{M})$, AziB-Svp (10 mg, section B), and $\sim 10 \mathrm{mg}$ of AziA6 or AziG were combined in $25 \mathrm{~mL}$ of AziB-AziG reaction buffer. The reaction was incubated at $30{ }^{\circ} \mathrm{C}$ overnight at $250 \mathrm{rpm}$. The reaction solution was filtered with centrifugal ultrafiltration units ( $3 \mathrm{kDa} \mathrm{MW}$ cutoff) and the filtrate was extracted with an equal volume of ethyl acetate three times. After drying the organics over anhydrous sodium sulfate, the sample was evaporated to dryness with a gentle flow of dry nitrogen gas.

\section{LC/MS Analysis of In vitro Reaction Products}

Product formation was analyzed by LC/MS. Samples were dissolved in $100 \mu \mathrm{L}$ of methanol, and 10-30 $\mu \mathrm{L}$ of the sample was injected onto the reversed-phase LC/MC equipped with a Phenomenex column (Columbus $5 \mu \mathrm{C} 8100 \mathrm{~A}, 250 \times 3.20 \mathrm{~mm} 5 \mu$ ), which was preequilibrated with $80 \% \mathrm{~A}$ (water) and 20\% B (75\% methanol and 25\% isopropanol). LC/MS conditions were as follows: Time 0 min A-80\% B-20\%; 1 min A-80\% B-20\%; 15 min A-0\% B-100\%; 30 min A-0\% B-100\%; 32 min A-80\% B-20\% till 40 min, flow rate $0.75 \mu \mathrm{L} / \mathrm{min}$. Sample elution was monitored by UV at $\lambda 254 \mathrm{~nm}$ and by mass, $136 \mathrm{~m} / \mathrm{z}$ for 2methylbenozoic acid and $187 \mathrm{~m} / \mathrm{z}$ for 5-methyl-1-naphthoic acid.

The synthetic compound standard, 5-methylnaphthoic acid, was either treated directly with AziB-AziG reaction buffer or treated first with acid or base prior to the addition of the buffer. These three samples and untreated compound were analyzed by LC/MS as detailed above. The base treated sample gave a single peak, which was also shown in the AziB-AziG reaction sample; co-injection confirmed the identity of the peak as 5-methylnaphthoic acid.

\section{Synthesis of 5-Methyl-1-Naphthoic Acid}

tert-Butyl 5-bromo-1-naphthoate ${ }^{\mathbf{1 7}}$-Oxalyl chloride $(0.4 \mathrm{~mL})$ was added to a suspension of 5-bromo-1-naphthoic acid (1.08 g) in dichloromethane $(9.3 \mathrm{~mL})$ containing 3 drops of dimethylformamide and the reaction mixture was stirred at ambient temperature for $6 \mathrm{~h}$. The solution was concentrated to afford a white solid, which was re-dissolved in tetrahydrofuran (THF). The solution was cooled to $2{ }^{\circ} \mathrm{C}$ and a solution of potassium tertbutoxide $(0.72 \mathrm{~g})$ in THF $(14.8 \mathrm{~mL})$ was added dropwise and stirred at ambient temperature for $3 \mathrm{~h}$. The solution was poured onto ice $(20 \mathrm{~g})$ and extracted with ethyl acetate $(2 \times 10$ $\mathrm{mL})$. The combined organic extracts were washed with water $(10 \mathrm{~mL})$, dried over sodium sulfate, and concentrated in vacuo. The residue was purified by flash column chromatography (cyclohexane: ethyl acetate $=1: 1$ ) to give 5-bromo-1-naphthoic acid tertbutyl ester in $91 \%$ yield $(12 \mathrm{~g}) .{ }^{1} \mathrm{H} \mathrm{NMR}\left(300 \mathrm{MHz}, \mathrm{CDCl}_{3}\right): \delta_{\mathrm{H}} 8.86(\mathrm{~d}, \mathrm{~J}=9.0 \mathrm{~Hz}, 1 \mathrm{H})$, $8.48(\mathrm{~d}, \mathrm{~J}=8.7 \mathrm{~Hz}, 1 \mathrm{H}), 8.13(\mathrm{dd}, \mathrm{J}=7.3, \mathrm{~J}=0.9 \mathrm{~Hz}, 1 \mathrm{H}), 7.86(\mathrm{dd}, \mathrm{J}=7.5, \mathrm{~J}=0.9 \mathrm{~Hz}, 1 \mathrm{H})$, $7.62(\mathrm{dd}, \mathrm{J}=8.6, \mathrm{~J}=7.5 \mathrm{~Hz}, 1 \mathrm{H}), 7.45(\mathrm{dd}, \mathrm{J}=8.7, \mathrm{~J}=7.5 \mathrm{~Hz}, 1 \mathrm{H}), 1.71(\mathrm{~s}, 9 \mathrm{H})$. 
tert-Butyl 5-methyl-1-naphthoate ${ }^{\mathbf{1 8}}$-To a solution of 5-bromo-1-naphthoic acid tertbutyl ester $(1.00 \mathrm{~g}, 3.26 \mathrm{mmol})$ in THF $(10 \mathrm{~mL}),-78^{\circ} \mathrm{C}$, was added n-butyllithium $(2.5 \mathrm{M}$ in hexanes, $1.56 \mathrm{~mL}$ ) over a period of $2 \mathrm{~min}$. After stirring for $40 \mathrm{~min}$, methyl iodide $(0.55$ g) was added. This reaction mixture was allowed to warm to room temperature over $1.5 \mathrm{~h}$. The reaction was quenched with water $(10 \mathrm{~mL})$ and partitioned between water and diethyl ether $(3 \times 50 \mathrm{~mL})$. The combined organic extracts were dried over $\mathrm{MgSO}_{4}$ and concentrated in vacuo. Purification of the residue by flash-chromatography (hexanes:EtOAc $=98: 2$ ) gave compound (3) in $84 \%$ yield $(660 \mathrm{mg}) .{ }^{1} \mathrm{H}-\mathrm{NMR}\left(300 \mathrm{MHz}, \mathrm{CDCl}_{3}\right): \delta_{\mathrm{H}} 8.70(\mathrm{~d}, J=8.7 \mathrm{~Hz}$, $1 \mathrm{H}), 8.20(\mathrm{~d}, J=8.7 \mathrm{~Hz}, 1 \mathrm{H}), 8.07(\mathrm{dd}, J=7.3, J=1.2 \mathrm{~Hz}, 1 \mathrm{H}), 7.56(\mathrm{~d}, J=7.2 \mathrm{~Hz}, 1 \mathrm{H})$, 7.54-7.48 (m, 1H), 7.42-7.37 (m, 1H), $2.75(\mathrm{~s}, 3 \mathrm{H}), 1.72(\mathrm{~s}, 9 \mathrm{H})$.

5-Methyl-1-naphthoic acid ${ }^{18}$-5-Methynaphthalene-1-carboxylic acid tert-butyl ester $(1.37 \mathrm{~g}, 4.45 \mathrm{mmol})$ was dissolved in dichloromethane $(10 \mathrm{~mL})$, and trifluoroacetic acid (3 $\mathrm{mL}$ ) was added. After stirring for $16 \mathrm{~h}$, the reaction was concentrated in vacuo to give compound (4) in quantitative yield. ${ }^{1} \mathrm{H}-\mathrm{NMR}\left(300 \mathrm{MHz}, \mathrm{CD}_{3} \mathrm{OD}\right.$ ): $\delta_{\mathrm{H}} 8.738 .74$ (d, $J=8.7$ $\mathrm{Hz}, 1 \mathrm{H}), 8.28(\mathrm{~d}, J=8.4 \mathrm{~Hz}, 1 \mathrm{H}), 8.18(\mathrm{dd}, J=7.2, J=1.2 \mathrm{~Hz}, 1 \mathrm{H}), 7.58(\mathrm{dd}, J=8.5, J=$ $7.2 \mathrm{~Hz}, 1 \mathrm{H}), 7.52-7.44(\mathrm{~m}, 1 \mathrm{H}), 7.44-7.36(\mathrm{~m}, 1 \mathrm{H}), 2.73(\mathrm{~s}, 3 \mathrm{H}) .{ }^{13} \mathrm{C} \mathrm{NMR}(125 \mathrm{MHz}$, $\left.\mathrm{CD}_{3} \mathrm{OD}\right): \delta_{\mathrm{C}} 20.0,125.0,125.5,125.8,128.0,128.1,130.0,130.4,132.6,134.3,135.9$, 171.5. MS (ESI): $\mathrm{m} / \mathrm{z}$ calculated for [M-H+] $\mathrm{C}_{12} \mathrm{H}_{9} \mathrm{O}_{2}$ 185.0603, found 185.0611 .

Kinetics of Hydrolysis Reaction Catalyzed by AziG-The kinetic parameters of AziG and its mutants were measured as the formation of 2-nitro-5-thiobenzoic acid (TNB) at $412 \mathrm{~nm}\left(\varepsilon=8,857.1 \mathrm{M}^{-1} \mathrm{~cm}^{-1}\right)$ as a function of time. The reagent, 5,5'-dithiobis(2nitrobenzoic acid) (DTNB or Ellman's reagent), reacts with free thiol produced by hydrolysis of 5-methyl-1-naphthoate-SNAC by AziGs, resulting in the TNB product. Absorbance readings were measured on a GENESYS ${ }^{\mathrm{TM}} 2$ UV-Vis Spectrometer (Thermo Fisher Scientific). The reaction was carried out in AziB-AziG reaction buffer without glycerol, which contains $0.4 \mathrm{mM}$ of DTNB, $20 \mu \mathrm{M}$ of AziGs, $0.1-0.5 \mathrm{mM}$ of the substrate, and $5 \%$ DMSO.

Three types of buffered solutions consisting of DTNB alone, AziG + DTNB, or substrate + DTNB were used to establish a control because DTNB and the substrate are chemically degraded by water molecules and AziG contains cysteine residues, which can react with DTNB. The effect of chemical degradation of DTNB, which was counted twice on the absorbance of two solutions ( $\mathrm{A}_{\text {AziG-DTNB }}$ and $\mathrm{A}_{\text {substrate-DTNB}}$ ) can be eliminated by utilizing the following equation:

$$
\mathrm{A}_{\text {control }}=\mathrm{A}_{\mathrm{AziG-} \text { DTNB }}+\mathrm{A}_{\text {substrate- DTNB }}-\mathrm{A}_{\mathrm{DTNB}}
$$

The control was used to correct these undesired effects with the following equation:

$$
\mathrm{A}_{\text {corrected }}=\mathrm{A}_{\mathrm{AziG}+\text { substrate+DTNB }}-\mathrm{A}_{\text {control }}
$$

The absorbance was observed continuously every $30 \mathrm{~s}$, and the rates of hydrolysis were determined from the initial linear component of the curves. The assays were performed at 
least 4 times for each data point. DMSO was used to solubilize the substrate. Since the solubility was highly limited even in 5\% DMSO, the velocity could be calculated only at low substrate concentrations. Therefore, the limited case of Michaelis-Menten kinetics where $[\mathrm{S}] \ll[\mathrm{Km}]$ was applied to obtain $\mathrm{k}_{\mathrm{cat}} / \mathrm{K}_{\mathrm{m}}$ values as the slope of the plotted linear graph of $\mathrm{V} /[\mathrm{E}]$ vs. $[\mathrm{S}]$ by the following equation:

$$
\frac{V}{[E]}=\frac{\mathrm{kcat}}{\mathrm{KM}}[\mathrm{S}]
$$

where $\mathrm{V}$ is velocity, $[\mathrm{E}]$ is concentration of AziGs, and $[\mathrm{S}]$ is concentration of the substrate.

Molar absorptivity of DTNB:

The molar absorptivity of TNB was calculated with the Beer-Lambert law:

$$
\mathrm{A}=\varepsilon \mathrm{cl}
$$

where $\mathrm{A}$ is the absorbance, $\varepsilon$ is the molar absorptivity $\left(\mathrm{M}^{-1} \mathrm{~cm}^{-1}\right), \mathrm{c}$ is the concentration $(\mathrm{M})$, and 1 is the path length $(\mathrm{cm})$. Since the path length is $1 \mathrm{~cm}$, the molar absorptivity was calculated as the slope of a linear graph of A vs. c.

The absorbance of TNB (412 nm) was measured, varying the substrate (5-methylnaphthoate-SNAC) concentration. The reaction mixture contained $50 \mathrm{mM}$ potassium phosphate at $\mathrm{pH}$ 7.5, 0.4 mM DTNB, 5\% DMSO, and varying concentrations of 5-methylnaphthoate-SNAC $(0.1,0.25,0.4$, and $0.5 \mathrm{mM})$.

Assaying for Background Hydrolytic Activity-As a negative control, to assay for contaminating hydrolytic activity, the AziG purification procedure was carried out with $E$. coli BL21(DE3) harboring pET-24a (no insert). The eluted column buffer solution was subjected to kinetic analysis as detailed above.

Synthesis of 5-Methyl-1-Naphthoate-SNAC Ester-5-methyl-1-naphthoic acid (55 $\mathrm{mg}, 0.3 \mathrm{mmol}$ ), (3-dimethylaminopropyl)-3-ethylcarbodiimide hydrochloride (114 mg, 0.6 mmol), DMAP (37 mg, $0.3 \mathrm{mmol}$ ), N-acetylcysteamine (SNAC) $(35 \mathrm{mg}, 0.3 \mathrm{mmol}$ ) and triethylamine $(60 \mathrm{mg}, 0.6 \mathrm{mmol})$ were stirred in dichloromethane $(10 \mathrm{~mL})$ under argon at room temperature overnight. The organic layer was washed with saturated $\mathrm{NaHCO}_{3}$ solution, $0.1 \mathrm{~N} \mathrm{HCl}$ solution and brine $(10 \mathrm{~mL}$ of each). The organics were dried over anhydrous sodium sulfate, concentrated in vacuo and purified by flash column chromatography (dichloromethane) to provide pure white solid product in $81 \%$ yield (70 mg). 1H NMR (300 MHz, CDCl3): $\delta \mathrm{H} 1.99$ (s, 3H), 2.71 (s, 3H), 3.27 (t, J = 6.3 Hz, 2H), 3.59 (q, J = 6.3 Hz, 2H), $6.11(\mathrm{~s}, 1 \mathrm{H}), 7.38(\mathrm{~d}, \mathrm{~J}=7.2 \mathrm{~Hz}, 1 \mathrm{H}), 7.44-7.55(\mathrm{~m}, 2 \mathrm{H}), 8.01(\mathrm{~d}$, $\mathrm{J}=7.2 \mathrm{~Hz}, 1 \mathrm{H}), 8.19(\mathrm{~d}, \mathrm{~J}=8.4 \mathrm{~Hz}, 1 \mathrm{H}), 8.28(\mathrm{~d}, \mathrm{~J}=8.7 \mathrm{~Hz}, 1 \mathrm{H}) .13 \mathrm{C}$ NMR $(75 \mathrm{MHz}$, CDCl3): 195.05, 170.4, 135.7, 134.7, 132.9, 129.2, 129.0, 127.7, 127.5, 127.3, 124.3, 123.2, 39.7, 29.5, 23.3, 19.8. MS (ESI): $\mathrm{m} / \mathrm{z}$ calculated for [C16H17NO2S + $\mathrm{Li}+] 294.1140$, found 294.113 


\section{RESULTS AND DISCUSSION}

Evaluation of the azinomycin biosynthetic gene cluster by BLAST analysis reveals the presence of a Type I iterative PKS, denoted aziB containing KS-AT-DH-KR-ACP catalytic domains. ${ }^{3,19}$ In vivo experiments on this PKS have suggested that AziB alone is responsible and sufficient for the biosynthesis of 5-methylnaphthoate. ${ }^{20}$ The AziB protein was successfully cloned and overexpressed in E. coli giving a $187 \mathrm{kDa}$ His-tagged apo-enzyme form of the PKS that was successfully purified by Ni-NTA chromatography (Fig. S1). Reconstitution of PKS activity was initially demonstrated by incubation of AziB with $S$. sahachiroi cell-free extracts (CFE). Conversion to the azinomycin naphthoate was detected by the incorporation of ${ }^{14} \mathrm{C}$-malonyl coenzyme A (MAL CoA) as shown by TLC/ autoradiographic analysis and HPLC/scintillation counting (Figure 2 and Fig. S3-S4).

An enhancement in naphthoate production was observed when apo-AziB was added to CFE. As PKS activity was successfully reconstituted by incubation with $S$. sahachiroi CFE, we sought to activate the PKS directly with a phosphopantetheinyl transferase (PPTase). Activation was successfully achieved by incubation of AziB with the PPTase from Streptomyces verticillus ${ }^{21}$ and coenzyme $\mathrm{A}$ as shown by use of ${ }^{3} \mathrm{H}$-pantetheine CoA and autoradiographic analysis (Fig. S2). The AziB holo-PKS was evaluated for the production of 5-methylnaphthoic acid by incubation with radiolabeled precursors and NADPH (Figure $3 \mathrm{~A})$. Following treatment of the reaction mixture with base and subsequent neutralization, the resulting metabolites were extracted and the products visualized by TLC/ autoradiography. In comparison to the control lanes, lanes 5 and 6 (duplicate samples) showed the appearance of a prominent spot (highlighted in red); the $\mathrm{R}_{\mathrm{f}}$ value was significantly lower than that shown for naphthoic acid shown in lane 7 . The in vitro reaction was thus performed in large scale with unlabeled substrates, which led to the production of one primary metabolite (Figure 3B). Structural characterization of the compound by NMR (Fig. S6-S7) and MS revealed the compound as 2-methylbenzoic acid, a truncated PKS product. Evaluation of AziB by MALDI-MS (Fig. S5) revealed that the protein was expressed intact and was not frame shifted or mutated. Hence, we hypothesized that a domain was likely missing; in the absence of the domain, we obtain 2-methylbenzoic acid as a result of condensation between an acetate unit and 3 malonate units. In contrast, in the presence of the domain, 5-methylnaphthoic acid is generated, formed through condensation of an acetate unit with 5 malonate units. As thioesterase (TE) domains typically catalyze the release of a nascent fatty acid or polyketide chain from that of an FAS or PKS by direct hydrolysis or cyclization, we envisioned that a TE domain might catalyze this process. ${ }^{22}$ Evaluation of the azinomycin biosynthetic gene cluster reveals the presence of four putative TE domains: AziA6, AziA7, AziA8 and AziG, none of which are physically associated with the PKS. AziA6 (29.6 kDa) and AziA7 (27.4 kDa) are adjacent or associated with NRPS genes AziA3 and AziA4, respectively. AziA6, AziA7 and AziA8 (27.8 kDa) are each putative Type II thioesterases based upon protein sequence homology to known thioesterases. They each exhibit at least $32 \%$ identity and $47 \%$ similarity to a Type II thioesterase from Amycolatopsis mediterranei. ${ }^{23}$ The TE domains are discrete units with proposed editing functions, i.e. possess the ability to release any mis-bound substrates or intermediates. ${ }^{24} \mathrm{AziG}$ is a comparatively smaller protein $(14.4 \mathrm{kDa})$ of the thioesterase 
superfamily. All four TE domains were individually cloned with His-tags, expressed in $E$. coli and subsequently purified by Ni-NTA chromatography. LC/MS analysis was performed on the holo-PKS reaction with and without each of the TE domains (Figure 4). Analysis of AziB alone gives an $m / z$ of $137.07[\mathrm{M}+\mathrm{H}]$, corresponding to 2-methylbenzoic acid and was confirmed by co-injection (Fig. S9). Incubation of AziB with AziG showed a decrease in the formation of the 2-methylbenzoic acid peak with a new peak forming with an $\mathrm{m} / \mathrm{z}$ of 187.14 $[M+H]$. LC/MS analysis of a synthetic standard utilizing the same buffer conditions, confirmed the production of 5-methylnaphthoic acid. This result was further corroborated by co-injection (Fig. S10). None of the other TE domains (AziA6, AziA7, AziA8) were capable of catalyzing the reaction (Fig. S11). Gel filtration analysis of AziB with AziG does not reveal a stable complex, which suggests that the complex is formed transiently or is below our level of detection (Fig. S14). The few available crystal structures of TE domains reveal an $\alpha / \beta$ hydrolase fold with the presence of a GXSXG motif and three canonical TE catalytic triad residues within the active site consisting of amino acids Ser-His-Asp. ${ }^{25}$ Serine serves as the nucleophile to which the polyketide would be covalently bound, histidine serves as a general base deprotonating the serine and aspartate in its deprotonated state neutralizes the developing charge on the histidine.

By primary sequence comparisons, we could not identify a GXSXG motif or the Ser-HisAsp catalytic triad in AziG. The X-ray crystal structure of AziG was determined at $2.15 \AA$. As our biochemical assays suggested that AziG might be involved in generating the azinomycin naphthoate, AziG crystals were soaked in a solution containing 5methylnaphthoic acid. Data were collected to $2.2 \AA$ for the AziG/5-methylnaphthoic acid complex. AziG forms a tetramer with four 5-methylnaphthoic acid binding sites at the interface of two AziG chains (Figure 5A), as supported by gel-filtration analysis (Fig. S12S13). The 5-methylnaphthoate bound structure reveals the active site locations at the $\mathrm{AB}$ and CD interfaces, with two binding sites in each interface. Each cavity is approximately $7 \AA$ in diameter and $20 \AA$ deep. The AziG protomer displays the characteristic hotdog fold in which the antiparallel $\beta$-sheet surrounds a long $\alpha$-helix (Figure 5B). Three additional a-helices 1, 2 and 4 are short secondary structural elements of only three to five amino acids found within the long loop regions of AziG.

Within the active site, the 5-methylnaphthoic acid carboxy group interacts with Ser61, Glu57, Ser58, His48', and His44' (Figure 6, the prime designates amino acid residues within the opposing subunit). The AziG/5-methylnaphthoic acid bound structure enables us to identify possible catalytic residues. We have considered three possible mechanisms. We evaluated a serine hydrolase mechanism as TE domains from bacterial modular PKSs, fungal PKSs, NRPSs and human FAS have each been reported to follow a serine hydrolase mechanism involving Ser-His-Asp. ${ }^{25-28}$ BLAST analysis and a DALI structural search alignment against the PDB, however, do not reveal PKS, NRPS, or FAS TE domains as close relatives. Based upon these analysis tools AziG is most highly related to PaaI, a phenylacetic acid degradation protein from Thermus thermophilus (PDB ID: 1WLV), ${ }^{29}$ and 4-hydroxybenzoyl-CoA thioesterase, fromAnthrobacter sp. SU (PDB ID: 1Q4S), resulting in RMSD values of 1.1 and $1.3 \AA$, respectively. ${ }^{30}$ These thioesterases both share $31 \%$ 
sequence identity with AziG. As such we considered both a base catalyzed hydrolytic mechanism and a hydrolytic cleavage of an enzyme-anhydride intermediate mechanism.

All of the polar residues in the aziG active site shell were individually mutated. Hydrolytic activity of wild-type AziG and its respective mutants was assayed utilizing a DTNB (5,5'dithio-2-nitrobenzoic acid) assay and the $N$-acetylcysteamine (NAC) analog of the azinomycin naphthoate. NAC thioesters have been shown to be effective surrogates for the natural ACP-bound substrates, where the NAC serves as a mimic of the phosphopantetheine (PPT) arm of the ACP. DTNB allows for the detection of released free thiol by monitoring the progress of the reaction spectrophotometrically at $412 \mathrm{~nm}$. The reaction was carried out in the absence of any thiol reducing agents to decrease background absorbance. An assay of this type was utilized to evaluate the TE domain of the erythromycin polyketide synthase. ${ }^{31}$ However, the catalytic activity of wild-type AziG and its corresponding mutants was low (Table 1, Fig. S15-S16)). To further substantiate these results, we assayed for contaminating hydrolytic activity. No contaminating background activity was observed. Mutants resulted in a 2-3 fold reduction in rate and were not distinguishable. The low catalytic competency for the AziG catalyzed reaction $\left(k_{\mathrm{cat}} / K_{\mathrm{m}}=1.1 \mathrm{M}^{-1} \mathrm{~s}^{-1}\right)$, suggests that the active hydrolase requires association between AziB and AziG to form the fully active enzyme. Additional evidence for a complex, albeit a low affinity one, comes from the observation that the product of AziB is different in the presence and absence of AziG. We have tested 5methylnaphthoyl-NAC as a substrate for AziB and see no clear enhancement in the hydrolysis rate suggesting that AziB requires covalently attached product in order for AziG activation to occur. However, we are currently unable to test this due to the low levels of phosphopantetheinylation of AziB. Experiments designed to evaluate these hypotheses are currently in progress.

\section{CONCLUSION}

The azinomycin PKS system is unique. While DNA annotation would lead one to expect that the polyketide synthase AziB would catalyze the formation of the naphthoate ring system (a two-membered aromatic ring system), a truncated single-ring product, 2methylbenzoic acid, is formed instead. The thioesterase AziG behaves as a chain elongating and cyclization (CEC) domain and works in concert with AziB to enable the additional two rounds of chain extension needed to form the correct product, 5-methylnaphthoic acid. From an evolutionary perspective, the azinomycin PKS system appears to be a hybrid involving a Type I PKS and a Type II thioesterase domain.

\section{Supplementary Material}

Refer to Web version on PubMed Central for supplementary material.

\section{Acknowledgments}

Funding Sources

We are grateful to the National Science Foundation (CHE-1308151, C.M.H.W.; CHE-1308222, S.E.E.), the National Institutes of Health (T32 GM008500, M.S.E.), and the Welch Foundation (A-1828, C.M.H.W.) for financial support. Beam time was provided by the Advanced Photon Source on the Northeastern Collaborative 
Access Team beamlines (P41 GM103403 and S10 RR029205 from the National Institutes of Health). Use of the Advanced Photon Source is supported by the U.S. Department of Energy, Office of Basic Energy Sciences, under Contract No. DE-AC02-06CH11357. Use of the Cornell High Energy Synchrotron Source is supported by the National Science Foundation (DMR-0936384), and National Institutes of Health (P41 GM103485).

The authors would like to thank Benjamin Philmus, Yiquan Liu, and Yindrila Chakrabarty for LC/MS analyses and Tadhg P. Begley for helpful discussions.

\section{ABBREVIATIONS}

\begin{tabular}{ll} 
CEC domain & chain elongating and cyclization \\
PKS & polyketide synthase \\
FAS & fatty acid synthase \\
AT & acyl transferase \\
ACP & acyl carrier protein \\
KS & ketosynthase \\
KR & ketoreductase \\
DH & dehydratase \\
ER & enoyl reductase \\
TE & thioesterase \\
NRPS & non-ribosomal peptide synthetase \\
CFE & cell free extract \\
PPTase & phosphopantetheinyltransferase \\
SVP & Streptomyces verticillus \\
CoA & coenzyme A \\
NADPH & nicotinamide adenine dinucleotide phosphate \\
NAC & N-acetylcysteamine \\
DMAP & 4-dimethylaminopyridine \\
DTNB & 5,5'-dithio-2-nitrobenzoic acid \\
TNB & 2-nitro-5-thiobenzoic acid \\
PDB & protein data bank \\
BLAST & basic local alignment search tool \\
TLC & thin layer chromatography \\
HPLC & high performance liquid chromatography \\
LC/MS & liquid chromatography/mass spectrometry \\
\hline
\end{tabular}




\section{References}

1. Smith S, Tsai SC. The Type I Fatty Acid and Polyketide Synthases: a Tale of Two Megasynthases. Nat Prod Rep. 2007; 24:1041-1072. [PubMed: 17898897]

2. Cronan JE, Thomas J. Chapter 17 Bacterial Fatty Acid Synthesis and its Relationships with Polyketide Synthetic Pathways. Meth Enzymol. 2009; 459:395-433. [PubMed: 19362649]

3. Foulke-Abel J, Agbo H, Zhang H, Mori S, Watanabe CMH. Mode of Action and Biosynthesis of the Azabicycle-Containing Natural Products Azinomycin and Ficellomycin. Nat Prod Rep. 2011; 28:693-704. [PubMed: 21327255]

4. Shimada N, Uekusa M, Denda T, Ishii Y, Iizuka T, Sato Y, Hatori T, Fukui M, Sudo M. Clinical Studies of Carzinophilin, an Antitumor Substance. J Antibiot (Tokyo). 1955; 8:67-76. [PubMed: 13271243]

5. Sharma V, Kelly GT, Watanabe CMH. Exploration of the Molecular Origin of the Azinomycin Epoxide: Timing of the Biosynthesis Revealed. Org Lett. 2008; 10:4815-4818. [PubMed: 18841989]

6. Nepal KK, Lee RP, Rezenom YH, Watanabe CMH. Probing the Role of N-Acetyl-glutamyl 5Phosphate, an Acyl Phosphate, in the Construction of the Azabicycle Moiety of the Azinomycins. Biochem. 2015; 54:4415-4418. [PubMed: 26161634]

7. Zang H, Gates KS. DNA Binding and Alkylation by the "Left Half" of Azinomycin B. Biochem. 2000; 39:14968-14975. [PubMed: 11101313]

8. Coleman RS, Perez RJ, Burk CH, Navarro A. Studies on the Mechanism of Action of Azinomycin B: Definition of Regioselectivity and Sequence Selectivity of DNA Cross-link Formation and Clarification of the Role of the Naphthoate. J Am Chem Soc. 2002; 124:13008-13017. [PubMed: 12405827]

9. Otwinowski, Z.; Minor, W. Processing of X-ray Diffraction Data Collected in Oscillation Mode. In: Carter, CWJ.; Sweet, RM., editors. Methods Enzymol. Academic Press; New York: 1997. p. 307-326.

10. Matthews BW. Solvent content of protein crystals. J Mol Biol. 1968; 33:491-497. [PubMed: 5700707]

11. Stein N. CHAINSAW: a program for mutating pdb files used as templates in molecular replacement. Journal of Applied Crystallography. 2008; 41:641-643.

12. Vagin A, Teplyakov A. An approach to multi-copy search in molecular replacement. Acta Crystallogr D. 2000; 56:1622-1624. [PubMed: 11092928]

13. Emsley P, Lohkamp B, Scott WG, Cowtan K. Features and development of Coot. Acta Crystallogr D Biol Crystallogr. 2010; 66:486-501. [PubMed: 20383002]

14. Murshudov GN, Skubak P, Lebedev AA, Pannu NS, Steiner RA, Nicholls RA, Winn MD, Long F, Vagin AA. REFMAC5 for the refinement of macromolecular crystal structures. Acta Crystallogr D Biol Crystallogr. 2011; 67:355-367. [PubMed: 21460454]

15. Adams PD, Afonine PV, Bunkoczi G, Chen VB, Echols N, Headd JJ, Hung LW, Jain S, Kapral GJ, Grosse Kunstleve RW, McCoy AJ, Moriarty NW, Oeffner RD, Read RJ, Richardson DC, Richardson JS, Terwilliger TC, Zwart PH. The Phenix software for automated determination of macromolecular structures. Methods. 2011

16. Chen VB, Arendall WB 3rd, Headd JJ, Keedy DA, Immormino RM, Kapral GJ, Murray LW, Richardson JS, Richardson DC. MolProbity: all-atom structure validation for macromolecular crystallography. Acta Crystallogr D Biol Crystallogr. 66:12-21. [PubMed: 20057044]

17. Cassayre JY, Renold P, Pitterna T, Bobosik V, El QM, Dalencon AJ, Zambach W, Godfrey CR, Jung PJ, Pabba J. Insecticidal compounds. Google Patents. 2010

18. Barba O, Dawson GJ, Krulle TM, Rowley RJ, Smyth D, Thomas GH. Dihydroimidazothiazole derivatives. Google Patents. 2006

19. Zhao Q, He Q, Ding W, Tang M, Kang Q, Yu Y, Deng W, Zhang Q, Fang J, Tang G, Liu W. Characterization of the Azinomycin B Biosynthetic Gene Cluster Revealing a Different Iterative Type I Polyketide Synthase for Naphthoate Biosynthesis. Chem Biol. 2008; 15:693-705. [PubMed: 18635006] 
20. Ding W, Deng W, Tang M, Zhang Q, Tang G, Bi Y, Liu W. Biosynthesis of 3-Methoxy-5-Methyl Naphthoic Acid and its Incorporation into the Anti-tumor Antibiotic Azinomycin B. Mol BioSys. 2010; 6:1071-1081.

21. Sanchez C, Du L, Edwards DJ, Toney MD, Shen B. Cloning and Characterization of a Phosphopantetheinyl Transferase from Streptomyces verticillus ATCC15003, the Producer of the Hybrid Peptide-Polyketide Antitumor Drug Bleomycin. Chem Biol. 2001; 8:725-738. [PubMed: 11451672]

22. Cantu DC, Chen Y, Reilly PJ. Thioesterases: A New Perspective Based on Their Primary and Tertiary Structures. Protein Sci. 2010; 19:1281-1295. [PubMed: 20506386]

23. Claxton HB, Akey DL, Silver MK, Admiraal SJ, Smith JL. Structure and Functional Analysis of RifR, the Type II Thioesterase from the Rifamycin Biosynthetic Pathway. J Biol Chem. 2009; 284:5021-5029. [PubMed: 19103602]

24. Heathcote ML, Staunton J, Leadlay PF. Role of Type II Thioesterases: Evidence for Removal of Short Acyl Chains Produced by Aberrant Decarboxylation of Chain Extender Units. Chem Biol. 2001; 8:207-220. [PubMed: 11251294]

25. Korman TP, Crawford JM, Labonteb JW, Newman AG, Wong J, Townsend CA, Tsai SC. Structure and Function of an Iterative Polyketide Synthase Thioesterase Domain Catalyzing Claisen Cyclization in Aflatoxin Biosynthesis. Proc Natl Acad Sci USA. 2010; 107:6246-6251. [PubMed: 20332208]

26. Tsai SC, Miercke LJ, Krucinski J, Gokhale R, Chen JC, Foster PG, Cane DE, Khosla C, Stroud RM. Crystal Structure of the Macrocycle-Forming Thioesterase Domain of the Erythromycin Polyketide Synthase: Versatility from a Unique Substrate Channel. Proc Natl Acad Sci USA. 2001; 98:14808-14813. [PubMed: 11752428]

27. Bruner SD, Weber T, Kohil RM, Schwarzer D, Marahiel MA, Walsh CT, Stubbs MT. Structural basis for the cyclization of the lipopeptide antibiotic surfactin by the thioesterase domain SrfTE. Structure. 2002; 10:301-310. [PubMed: 12005429]

28. Pemble CWI, Johnson LC, Kridel SJ, Lowther WT. Crystal Structure of the Thioesterase Domain of Human Fatty Acid Synthase Inhibited by Orlistat. Nat Struct Mol Biol. 2007; 14:704-709. [PubMed: 17618296]

29. Kunishima N, Asada Y, Sugahara M, Ishijima J, Nodake Y, Sugahara M, Miyano M, Kuramitsu S, Yokoyama S, Sugahar M. A Novel Induced-fit Reaction Mechanism of Asymmetric Hot Dog Thioesterase PaaI. J Mol Biol. 2005; 352:212-228. [PubMed: 16061252]

30. Song F, Thoden JB, Zhuang Z, Latham J, Trujillo M, Holden HM, Dunaway-Mariano. The Catalytic Mechanism of the Hotdog-fold Enzyme Superfamily 4-Hydroxybenzoyl-CoA Thioesterase from Arthrobacter sp. Strain SU. Biochem. 2012; 51:7000-7016. [PubMed: 22873756]

31. Gokhale RS, Hunziker D, Cane DE, Khosla C. Mechanism and Specificity of the Terminal Thioesterase Domain from the Erythromycin Polyketide Synthase. Chem Biol. 1999; 6:117-125. [PubMed: 10021418] 


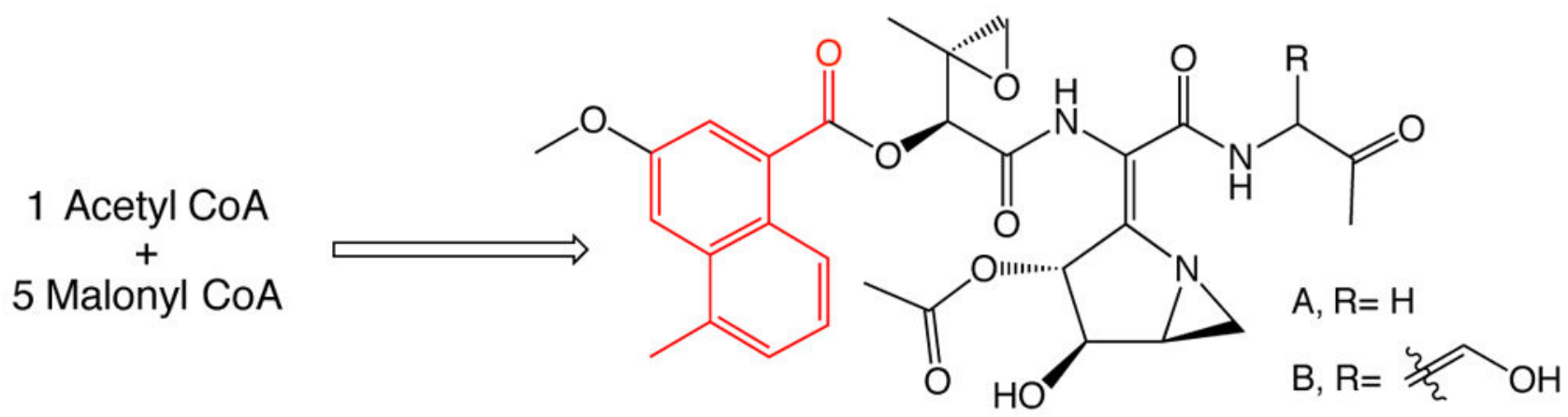

Figure 1.

Chemical structures of the azinomycins with the naphthoate portion highlighted in red. The naphthoate is assembled by homologation of an acetyl CoA starter unit with 5 malonyl CoA units. 


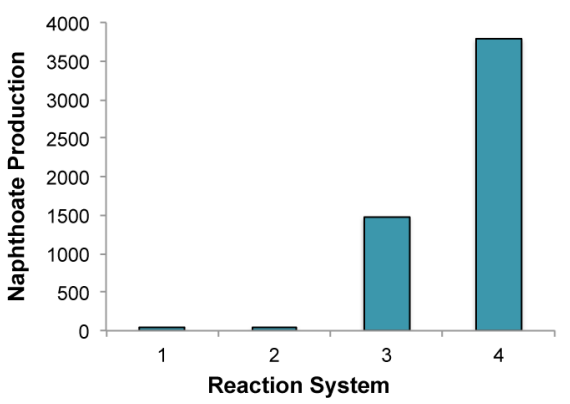

\begin{tabular}{c|l}
\hline Rxn & DPM \\
\hline \hline 1 & $43 \pm 3$ \\
2 & $36 \pm 4$ \\
3 & $1483 \pm 391$ \\
4 & $3794 \pm 475$ \\
\hline
\end{tabular}

Figure 2.

Evaluation of PKS Activity with $S$. sahachiroi Cell-Free Extracts: [1] Boiled CFE $+{ }^{14} \mathrm{C}$ MAL CoA, [2] Boiled CFE + PKS $+{ }^{14} \mathrm{C}$ MAL CoA, [3] CFE $+{ }^{14} \mathrm{C}$ MAL CoA, [4] CFE + $\mathrm{PKS}+{ }^{14} \mathrm{C}$ MAL CoA; assays run in triplicate (S1-S3) 
A B

$\begin{array}{lllllll}1 & 2 & 3 & 4 & 5 & 6 & 7\end{array}$

Figure 3.

Reconstitution of AziB Activity in vitro. Panel A: [1] ${ }^{14} \mathrm{C}$ Ac CoA, [2] ${ }^{14} \mathrm{C}$ MAL CoA, [3] Boiled AziB $+{ }^{14} \mathrm{C}$ Ac CoA $+{ }^{14} \mathrm{C}$ MAL CoA, [4] Boiled AziB $+{ }^{14} \mathrm{C}$ Ac CoA $+{ }^{14} \mathrm{C}$ MAL $\mathrm{CoA},[5] \mathrm{AziB}+{ }^{14} \mathrm{C}$ Ac CoA $+{ }^{14} \mathrm{C}$ MAL CoA, [6] AziB $+{ }^{14} \mathrm{C}$ Ac CoA $+{ }^{14} \mathrm{C}$ MAL CoA, [7] naphthoic acid control; Panel B: Iodine stained TLC plate showing a single primary product formed upon scale up and incubation with unlabeled substrates. 

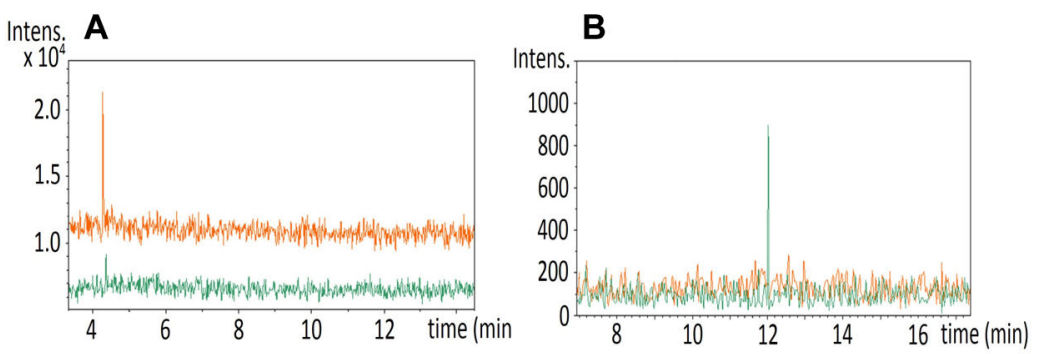

Figure 4.

Ion selected chromatograms of PKS reaction mixtures: [A] 2-methylbenzoic acid peak, 137.07 [M + H] [B] 5-methylnaphthoic acid peak, $187.14[\mathrm{M}+\mathrm{H}]$. The orange trace in both panels represent the PKS, AziB alone and the green trace represents the PKS, AziB + TE domain, AziG. 

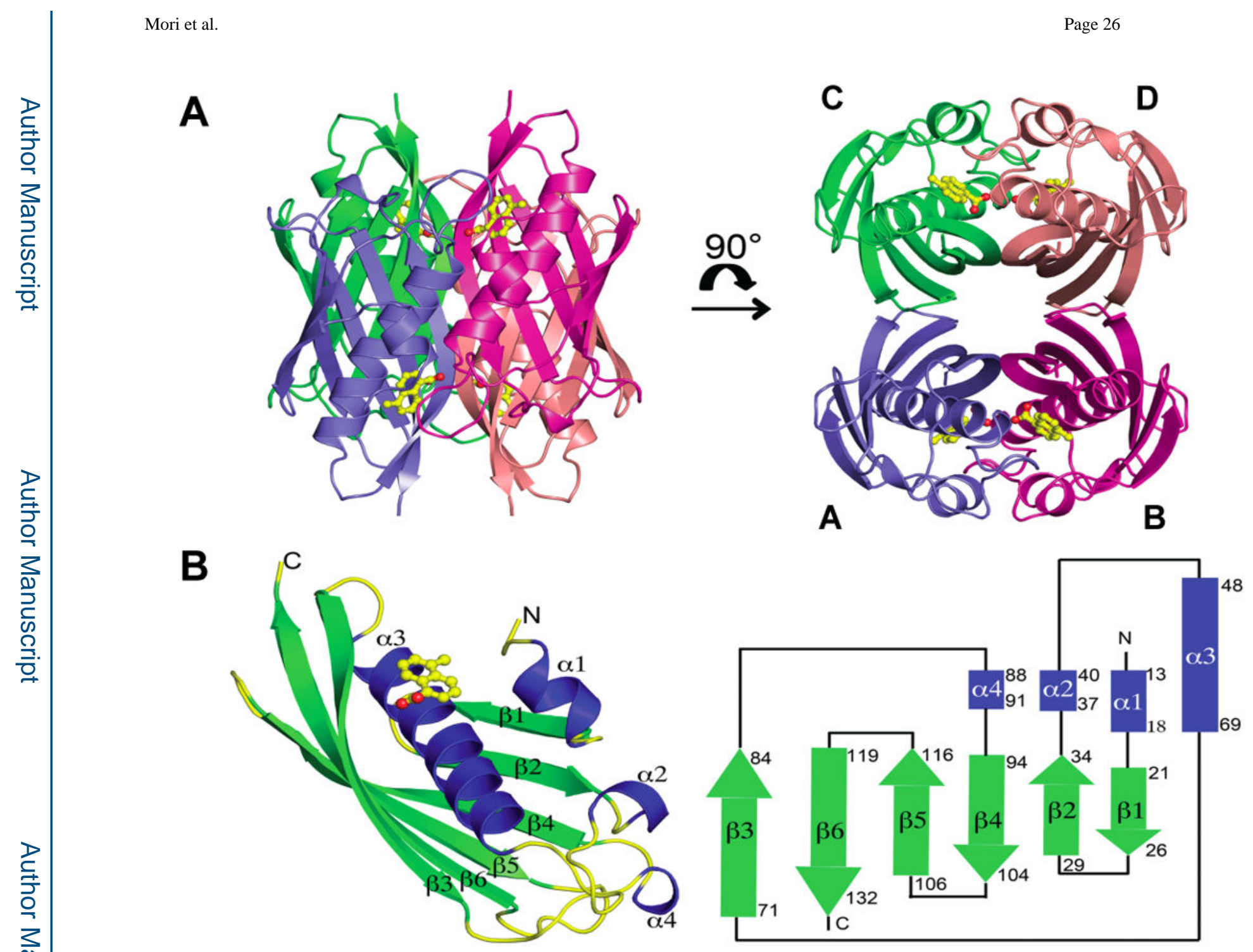

Figure 5.

X-ray crystal structure of AziG. [A] The biological tetramer formed by AziG. [B] The monomer adopts the characteristic hotdog fold with the $\beta$-sheet of each monomer facing the core and the main a-helices facing outward. 


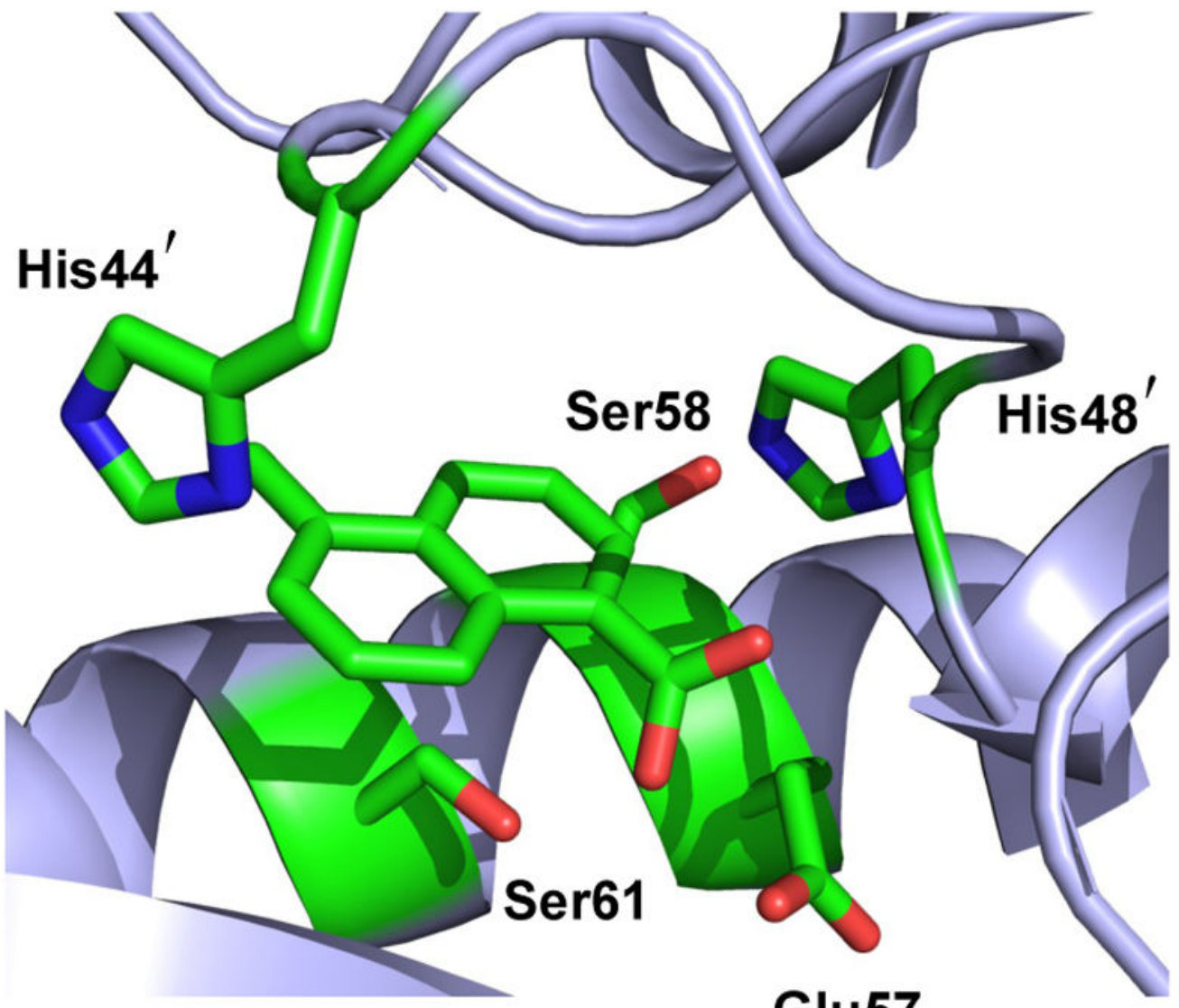

\section{Glu57}

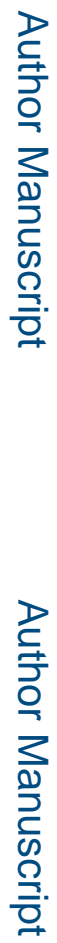

Figure 6.

Depictions of AziG active site. 5-methylnaphthoic acid within the AziG active site 


\section{Table 1}

\begin{tabular}{|c|c|}
\hline AziG Thioesterase & $k_{\mathrm{cat}} / K_{\mathrm{m}}\left(\mathrm{M}^{-1} \mathrm{~s}^{-1}\right)$ \\
\hline WT & $1.1 \pm 0.04$ \\
\hline $\mathrm{H} 44 \mathrm{~A}$ & $0.56 \pm 0.02$ \\
\hline $\mathrm{H} 48 \mathrm{~A}$ & $0.36 \pm 0.03$ \\
\hline E57A & $0.40 \pm 0.03$ \\
\hline S58A & $0.37 \pm 0.03$ \\
\hline S61A & $0.46 \pm 0.04$ \\
\hline
\end{tabular}

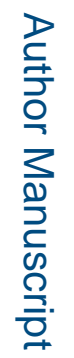

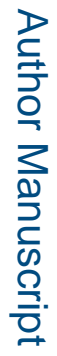

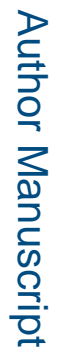

Biochemistry. Author manuscript; available in PMC 2017 February 02. 